\title{
Sosyal Medyada Markaların Kullandığı İçerik Stratejisinin Gönderi Popülaritesindeki Rolü: Türkiye'deki Bilişim Şirketleri Üzerine Bir Uygulama
}

\author{
DOI: $10.26466 /$ opus.523402 \\ * \\ Dilek Penpece Demirer ${ }^{*}-\underline{\text { Elife Özer }}{ }^{* *}$ \\ ${ }^{*}$ Doç. Dr., Adana Alparslan Türkeş Bilim ve Teknoloji Üni., İşletme Fakültesi, Adana / Türkiye \\ E-Posta: dpenpece@adanabtu.edu.tr \\ ORCID: 0000-0003-4493-625X \\ ** Arş.Gör.Dr., Adana Alparslan Türkeş Bilim ve Teknoloji Üni., İşletme Fakültesi, Adana Türkiye \\ E-Posta: efyilmaz@adanabtu.edu.tr \\ ORCID: $\underline{0000-0002-5834-7483}$ \\ Öz \\ Teknolojideki ilerlemelerle birlikte rekabetin yüksek olduğu bilişim sektöründe, şirketler yoğun rekabete \\ bir çözüm olarak markalaşmaya yönelmektedir. İnternet kullanımının oldukça yayginlaştığı günümüz \\ iş dünyasında, sürdürülebilir bir marka stratejisinin önemli araçlarından birisi de sosyal medyada \\ marka hayran sayfaları ve takipçileri oluşturmaktır. Markaların hayran sayfalarında etkili bir içerik \\ stratejisi oluşturmak, hedef kitle ile ilişkilerin kurulmasına ve geliştirilmesine katkı sağlamaktadır. Bu \\ bağlamda çalışma, sosyal medyada kullanılan içerik stratejisinin, marka gönderi popülerliği açısından \\ rolünü Türkiye'deki bilişim firmaları çerçevesinde incelemeye odaklanmıştır. Örneklem çerçevesi olarak \\ Türkiye'de donanım, hizmet ve yazılım alanında faaliyet gösteren bilişim şirketleri belirlenerek bu şir- \\ ketlerin sosyal medya (Facebook ve Twitter) paylaşımları incelenmiştir. Çalışmada içerik stratejileri; \\ içerik türü, içerik çevikliği, içerik bağlamı, gönderi türü ve gönderi günü kapsamında ele alınmıştır. \\ Marka gönderi popülaritesini belirleyen unsurlar ise beğenme, yorum, paylaşım ve emoji reaksiyonlar \\ sayısı olarak değerlendirilmiştir. Bulgular içerik türü, içerik çevikliği, içerik bağlamı ve gönderi türü- \\ nün markaların gönderi popülartesi bağlamında anlaml farklllıklar gösterdiği yönündedir.
}

Anahtar Kelimeler: İçerik Stratejisi, Marka Gönderi Popülerliği, Sosyal Medya, Bilişim Sektörü. 


\title{
The Role of Content Strategy on Brand Post's Popularity in Social Media: A Research on IT Firms in Turkey
}

\begin{abstract}
In the highly competitive IT sector, branding is seen as a solution in dealing with today's global challenges. In today's business world where the use of the Internet has become widespread, one of the important tools of a sustainable brand strategy is to create brand fan pages and reach a high number of followers on social media. Creating an effective content strategy in the fan pages of brands contributes to the establishment and development of effective relations with the target audience. In this context, the study focused on examining the role of the content strategy on the brand post's popularity in social media by evaluating the information technology companies in Turkey. The sample frame consists of IT firms from hardware, software and services sub-categories and their social media (Facebook and Twitter) posts were studied in the context. As the content strategies in the study; content type, content agility, content context, posting type and posting day were evaluated. The factors determining the brand post's popularity were evaluated as the number of likes, comments, shares and emoji reactions. The findings suggest that content type, content agility, content context and posting type differ significantly in the context of the brand post's popularity.
\end{abstract}

Keywords: Content Strategy, Brand Post's Popularity, Social Media, IT Sector. 


\section{Giriş}

Sosyal medya, kullanıcılar tarafından oluşturulan içeriği paylaşmayı ve kullanıcılar arası etkileşimi destekleyen web tabanlı uygulamaları temsil etmektedir ve temel anlamda kullanıcıların kişiselleştirilmiş profiller oluşturarak kendilerini ifade etmelerine olanak sağlayan bir platform niteliği taşımaktadır (Tafesse ve Wien, 2017). Bu anlamda sosyal medya, içerik oluşturmak, paylaşmak ve etkileşim yaratmak aracılığı ile çok sayıda insanı bir araya getirmektedir (Kietzmann ve diğerleri, 2011). İnsanları çok az maliyetle veya hiçbir maliyet olmadan birbirine bağlama potansiyeli ile dünya çapında yaygınlığı artmaya devam etmektedir (Keitzmann ve diğ., 2011; Tafesse, 2015). Global Digital'in 2018 raporuna göre dünyada 3.196 milyar aktif sosyal medya kullanıcısı bulunmaktadır ki bu, dünya nüfusunun kabaca yüzde 42 'sinin sosyal medya platformlarında aktif olduğu anlamına gelmektedir ve ayrıca son 12 ayda bu kullanıcıların sayısı \%13 artış göstermiştir (We Are Social, 2018). Aynı rapora göre, Türkiye'de ortalama 48 milyon aktif sosyal medya kullanicısı bulunmaktadır, bu da Türkiye nüfusunun yaklaşık yüzde 60'ının sosyal medyada aktif olduğunu göstermektedir (We Are Social, 2018). Her ne kadar bu rakamlar bireysel kullanımı kurumsal kullanımdan ayırt etmese de, şirketlerin pazarlama çalışmaları için muazzam bir potansiyele işaret ettiğini söylemek mümkündür.

Sosyal medya platformları şirketler açısından müşterileri ile ilişkileri geliştirmek için kullanılabilecek mükemmel bir araç niteliği taşımaktadır. Bu amaçla şirketler Facebook, Twitter, Instagram gibi sosyal ağ sitelerinde marka hayran ve takipçi sayfaları oluşturmaktır (De Vries, Gensler ve Leeflang Peter, 2012). Günümüzde kullanıcıların giderek artan bir oranda sosyal medyada markalarla etkileşim gerçekleştirdiği görülmektedir. Bu nedenle, bu yeni "müşteri güçlendirme" biçimlerine ayak uydurmak isteyen şirketlerin (Cova ve Pace, 2006), marka ile ilgili etkileşimlerin hedef müşterileri için çekiciliğini anlamaları gerekmektedir (Muntinga, Moorman ve Smit, 2011). 2017 yılında yapılan çalışmanın sonuçlarına göre, Milenyum kuşağının bir markayı sosyal medyada takip etme ihtimali \%48,6 iken X kuşağının \% 48,8 ve Baby Boomer kuşağının ise \% 24,5'tir 
(Sprout Social, 2017). Bu nedenle, marka hayran ve takipçi sayfaları oluşturmak, özellikle milenyum veya $X$ kuşağına (18-54 yaşları) odaklanan markalar için büyük bir potansiyel sunmaktadır.

Marka hayran sayfaları, müşterilerin marka ile olan ilişkisinin bir parçasinı oluşturmakta (McAlexander, Schouten ve Koenig, 2002) ve marka hakkında bilgi paylaşımında bulunmaktadır (Bagozzi ve Dholakia, 2002). Böylece markanın ününü artırmaktadır (Lipsman, Mudd, Rich ve Bruich, 2012). Marka hayran sayfalarında şirketler fotoğraf, video veya diğer materyalleri içeren marka gönderileri oluşturabilmektedirler (De Vries ve diğ., 2012). Bazı markaların gönderileri insanları kendine çekerek daha popüler hale gelirken; bazıları ise takipçiler tarafından göz ardı edilmektedir (Chua ve Banerjee, 2015). Takipçilerine cazip gelecek bu popüler gönderileri oluşturmak ve sürdürmek için içerik stratejilerini oluşturmada zorluk çekilmektedir (Chauhan ve Pillai, 2013). Bu çalışmanın kapsamında marka olarak ele alınan bilişim şirketlerinin, takipçileri ile olan ilişkilerini genişletebilecek dijital içerik stratejilerini tasarlamaları gerektiğinden yola çıkılmıştır. Popüler marka gönderileri sayesinde, bilişim firmaları mevcut ve gelecekteki müşteriler, çalışanlar, tedarikçiler ve benzeri paydaşlar ile bağlantı kurarak markasını güçlendirebilme fırsatı elde edebilirler. Bu bağlamda bu çalışma, sosyal medyadaki içerik stratejisinin, marka gönderi popülerliği üzerindeki rolünü bilişim şirketleri üzerinde araştırmaya odaklanmaktadır.

\section{Marka hayran sayfaları ve marka gönderi popülaritesi}

Sosyal medya, sosyal paylaşım siteleri (Facebook, Twitter gibi), bloglar (Blogger, Wordpress gibi), resim paylaşım siteleri (Flickr, Pinterest, İnstagram gibi), video paylaşım siteleri (YouTube gibi), wikiler (Wetpaint gibi), sosyal yer imleri web siteleri (Delicious gibi), içerik yer imleri web siteleri (MERLOT gibi) gibi platformları kapsamaktadır (Penpece, 2013). Sosyal paylaşım siteleri bazı benzerliklerine rağmen, tasarım itibarı ile çoğunlukla birbirinden oldukça farklıdır (Kietzmann ve diğ., 2011). Bu bakımdan, sosyal paylaşım sitelerini ayrı ayrı incelemek gerekmektedir (Trefzger ve diğerleri, 2016). 
Facebook günümüzde en büyük sosyal ağ sitesi olarak görünmektedir ve Google ve Youtube' dan sonra en çok ziyaret edilen üçüncü web sitesidir (Alexa Analitic, 2017). Bireylerin yanında markalar da Facebook tarafından 2007 yılında başlatılan bir uygulama ile kendileri için bir profil sayfası oluşturma imkanına sahip olmuştur (Chauhan ve Pillai, 2013). Dünya genelinde yaklaşık 65 milyon şirket profil sayfası Facebook'ta etkindir (Smith, 2017). Mevcut üyelerin Facebook arkadaşları da, marka hayranları için bir potansiyel oluşturmaktadır (Ellison ve diğ., 2011). Bu nedenle, marka sayfasının üyeleri diğer bireylerle marka arasında bir köprü işlevi görebilmektedir (Palazón ve diğ., 2015). Kullanıcılar, marka ile bağlantı kurmak istiyorlarsa, marka hayran sayfasını "beğenmek" zorundadır Kullanıcıların Facebook'ta zamanlarının en büyük kısmını bu kişisel haber kaynaklarına harcadıkları görülmektedir (Lipsman ve diğ., 2012). Bu nedenle, kullanıcılar hayran sayfaları tarafından paylaşılan marka gönderilerini görebilmektedirler. Markaların gönderi içerikleri, etkileşimi teşvik eden bir araç olarak görülmektedir (Sabate, Berbegal-Mirabent, Cañabate ve Lebherz, 2014). İçerikle ilgili faaliyetler hedef kitleye ulaşarak, izleyicilerin ilgisini çektiği takdirde şirket hakkında farkındalık yaratabilir ve marka ile kullanıcı arasında bir ilişki kurulabilir (Penpece, 2013). Ancak başarılı bir içerik hayranları tarafından benimsenebilir. Böylece, hayranların çevrimiçi davranışları sayesinde içerik popülerliğe ulaşmaktadır (Sabate ve diğ., 2014). Bunun yanında marka hayranları, yorum ve paylaşımlar yoluyla marka yayınlarıyla etkileşim sağlamaktadır (Chua ve Banerjee, 2015). Bazı çalışmalar, marka beğenisinin popülerliğini 'beğenme' sayısı ve marka ilanındaki 'yorum' sayısı olarak belirlerken (De Vries ve diğ., 2012; Sabate ve diğ., 2014; Tafesse, 2015); bazı çalışmalar ise 'beğenme', 'yorum' ve 'paylaşım' sayısı (Cho ve diğ., 2014; Chua ve Banerjee, 2015; Kim ve Yang, 2017) olarak değerlendirmiştir. Bu ölçütleri karşılaştırmak gerekirse sadece bir tıklama beğenmek için yeterli olurken, yorum ve paylaşım için ek işlem yapmak gerekmektedir. Bu da harcamaya gönüllü olunan ilave bir zaman ve emek anlamına gelmektedir. Bu noktadan hareketle Facebook, kullanıcının ekranında neyin gösterileceğini belirlemek için farklı davranışlara farklı ağırlıklar vermektedir. Dolayısıyla her bir davranışın stratejik önemi diğerinden farklı olabilir (Kim ve Yang, 2017). Bu bağlamda, her davranışa ayrı ayrı odaklanmak önemlidir. 
Güncel bir çalışmada (Kaur, Balakrishnan, Rana, ve Sinniah, 2018) sosyal medya kullanıcılarının tepkileri duygu ve düşünce yoğunluğunu ölçmede bir değişken olarak ele alınmıştır. Sözsüz bir cevap olarak tepki butonları kullanıcılar arasında oldukça yaygın bir hale gelmiştir. Dijital ortamda insan davranışı yerine geçen ve grafiksel olarak duyguları ifade etmek için kullanılan emojilerin bir uzantısı olan beş yeni seçenek 2016'da Facebook'un butonlarına eklenmiştir. Bu seçenekler sevme, kahkaha atma, şaşırma, üzülme ve kızma duygularını yansıtan emojilerden oluşmaktadır. Bu tepki butonları ABD Temyiz Mahkemesi tarafından modern bir konuşma şekli olarak kabul edilmiştir (Kaur ve diğ., 2018). Kullanıc1ların tepkilerini incelemek için emoji reaksiyonları bu çalışmada da değerlendirmeye alınmıştır.

Alandaki çalışmalar markalarının gönderi popülerliğinin, müşterilerin motivasyonunu (Muntinga ve diğ., 2011) ve markaların gönderilerinin niteliğini içeren iki faktörden etkilenebileceğini göstermektedir (De Vries ve diğ., 2012; Sabate ve diğ., 2014; Chua ve Banerjee, 2015; Tafesse, 2015; Kim ve Yang, 2017). Bunun yanında gönderilerin içerik türüne, bağlamına, çeviklik, etkileşim, canlılık ve yenilik gibi unsurlarına da vurgu yapılmaktadır. Markaların gönderi olarak paylaştığı içerikler, sıralı bir şekilde düzenlenen, alg1 oluşturma sürecini takip eder. Daha sonra popüler marka gönderileri olumlu tutumlar yaratır ve marka hakkında olumlu davranışlara yönlendirebilir (Peng, Fan ve Hsu, 2004).

Küresel anlamda şirketler, kullanıcılara ürün ve hizmet bilgilerini sunmak için sosyal ağ sitelerini yoğun bir şekilde kullanmaktadırlar, bu nedenle tüketicilerin satın alma niyetini daha fazla etkilemek ve beğenmelerini sağlamak için bu paylaşımların içeriğini dikkatlice planlamalıdırlar (Chiang ve Tseng, 2017). Günümüz işletmelerinin faaliyet gösterdiği çevrimiçi bağlamda rekabetçi çevrede, markaların izlediği gönderi içerik stratejisi giderek artan bir öneme sahip olmaktadır. Çevrimiçi iş davranışları grup ekonomisini doğrudan etkileme gücüne sahiptir, çünkü beğenme davranışı bir grup etkisi yaratabilir ve yeni tüketicilerin satın alma niyetlerini artırmaya teşvik edebilmektedir (Chiang ve Tseng, 2017). Çalışma içerik stratejisinin marka gönderilerinin beğeni, yorum ve paylaşımı içeren popülerliği üzerindeki rolünü anlamaya çalışmaktadır. 


\section{Bilişim sektörü ve sosyal medya kullanımı}

Günümüzde teknoloji, firmaların rekabetçiliğinde önemli bir paya sahiptir. Bilişim teknolojileri, bilgi sistemlerinin yönetilmesine atıfta bulunmaktadır ve bu sistemler bilgi oluşturmak, depolamak, paylaşmak ve kullanmak için kullanılan tüm teknoloji biçimlerini kapsar (Ceci ve Prencipe, 2008). Bu açıdan bilişim sektörü, veri toplama, depolama ve işlemeyi sağlayan donanım ve yazılımla ilgili tüm işletmeleri içerir (Ceci ve Prencipe, 2008) ve genel anlamda donanım, yazılım ve hizmet (ya da iletişim) olmak üzere üç alt sektörden oluşmaktadır (Aydın, 2012). Bu çalışmanın örnekleminde de söz konusu alt sektörlerden şirketlere yer verilmiştir.

Bilişim teknolojilerinde 1980'li yıllardan itibaren gerçekleşen hızlı ve büyük çaptaki gelişmeler iş dünyasında köklü değişimlere yol açmıştır (Aydın 2012). Bu gelişmeler sayesinde internet kullanımı giderek artan bir hızda yaygınlaşmıştır. Emek yoğun sermayeden bilginin sermaye dönüştüğü günümüzün küresel rekabet ortamında ülkeler, bilişim toplumu olma yönünde bir rekabet içindedir. Bireysel internet kullanımının yaygınlaşması ve akabinde ticari faaliyetlerin internet üzerinde yoğunlaşması işletmeleri değişime uyum sağlamak adına yeni yollar geliştirmeye yöneltmiştir. Web 2.0 teknolojileri olarak adlandırılan sosyal medya platformları şirketlerin operasyonlarını iyileştirmenin yanında müşteri, tedarikçi ve iş ortakları ile işbirliğini geliştirmede yeni fırsatlar doğurmuştur (Culnan, McHugh ve Zubillage, 2010). Şirketler sosyal medya uygulamalarını \%64 oranında şirket içi süreçlerde kullanırken, \%56 oranında müşterilerle iletişim kurmak için ve $\% 40$ oranında iş ortakları veya tedarikçilerle ilişkilerinde kullanmaktadır (McKinsey Quarterly, Eylül 2009). Aynı rapora göre, başarılı şirketlerin sosyal medyayı kullanarak çalışanlarının iş akışlarını birbirine entegre etme, müşteri ve tedarikçilerle bağ kurma, fikir paylaşma, bilgiye hızlı erişim, iletişim, seyahat ve operasyon giderlerini azaltma, çalışanların iş tatminini artırma ve ürünlerin piyasaya çıma süresini azaltmada avantaj elde etmektedir (McKinsey Quarterly, Eylül 2009).

Bilişim şirketlerinin teknolojiden maksimum faydayı sağlaması ve bu bağlamda sosyal medyayı da etkili kullanmaları gerekmektedir. Bu doğrultuda giderek daha fazla sayıda firma, müşterileri ile iletişim kurmak 
için Twitter, Facebook, bloglar ve forumlar gibi sosyal medya platformlarını kullanmaktadır (Culnan ve diğg., 2010). Yine Culnan ve diğ. (2010) de vurguladığı gibi, yalnızca çevrimiçi bir profil oluşturmak, bir firmanın sosyal medyadan değer üretmesi için yeterli değildir. Bunun için başarılı sosyal medya içerik stratejileri geliştirmek gerekmektedir. Şirketlerin sosyal medyadaki paylaşımları için geliştirdikleri içerik stratejilerinin gönderilerin popülerliğine ve bu sayede marka stratejilerine katkı sağlayacağ1 öngörülmektedir.

\section{Araştırmanın Metodolojisi}

Bu bölümde, gerçekleştirilen saha araştırmasının amacı ve önemi, araştırma modeli ve hipotezleri, araştırma evreni ve örneklemi, veri toplama aracı ile verilerin analizi ve bulgular aktarılmaktadır.

\section{Araştırmanın amacı ve önemi}

Türkiye'de bilişim pazarı son on yılda keskin bir şekilde gelişmiştir. 2011 yılında 49.2 milyar TL olan Türkiye bilişim pazarı büyüklüğü 2017 yılında 116.9 miyar TL'ye ulaşmıştır (www.karel.com.tr). Böylesine hızlı gelişen sektördeki markalar da bir marka stratejisini benimseme baskısını hissetmektedirler. Sosyal medya ile bilişim sektörü markalaşma stratejisini bütünleştirmek, bilişim şirketleri için büyük bir potansiyel sunmaktadır. Bir markanın sosyal medyadaki sayfası takipçilerle ve onların ötesindekilerle bir köprü işlevi gerçekleştirebilir. Bir marka gönderisi ile iç ve dış paydaşlar etkileşime teşvik edilebilir. Bu nedenle, benimsenen içerik stratejisi marka gönderi popülaritesi oluşturmak ve geliştirmek için önemlidir. Gönderi ile sunulan içeriğe ilişkin kullanılabilecek farklı stratejiler, gönderi popülaritesi üzerinde farklılıklar oluşturabilir. Bu bağlamda çalışmanın amacı, bilişim şirketlerinin sosyal medyada kullandığı içerik stratejisi ve marka gönderi popülaritesi arasında farklılık olup olmadığını saptamaktır. İçerik stratejisi ve marka gönderi popülaritesi çerçevesindeki rolü incelenerek bilişim alanına katkıda bulunmaya çalışılmaktadır. 


\section{Araştırmanın modeli ve hipotezler}

İlgili literatürde genel olarak markanın kullandığı içerik stratejisinin, takipçilerinin gönderi ile ilgili beğeni, yorum ve/veya paylaşım bakımından verdiği tepkileri nasıl etkilediğine odaklanılmıştır (De Vries ve diğ., 2012; Sabate ve diğ., 2014; Tafesse, 2015). Etkileşim olasılığını belirleyen her gönderinin kilit yönleri; içerik türü, içerik çevikliği, içerik bağlamı, gönderi türü ve gönderi günü gibi faktörlere bağlanmaktadır. Marka ile sosyal medyadaki müşteri ilişkileri, beğeniler, yorumlar ve/veya paylaşımlar şeklinde tüm bu faktörlere bağlı olabilir. Ayrıca son dönemde gönderilere duygu aktarmayı kolaylaştıran emoji reaksiyonları da (Kaur ve diğ., 2018), markanın gönderi popülerliğini artıran bir diğer unsur olarak ele alınabilir. Sadece Facebook'da mevcut olan bu özellik çalışmada ele alınacaktır. Twitter için ise, bu özellik var olmadığından markanın gönderi popülerliği beğenme, yorum ve paylaşım sayısı olarak ele alınacaktır. Dolayısıyla araştırma modeli Şekil 1'deki gibi geliştirilmiş ve gösterilmiştir.

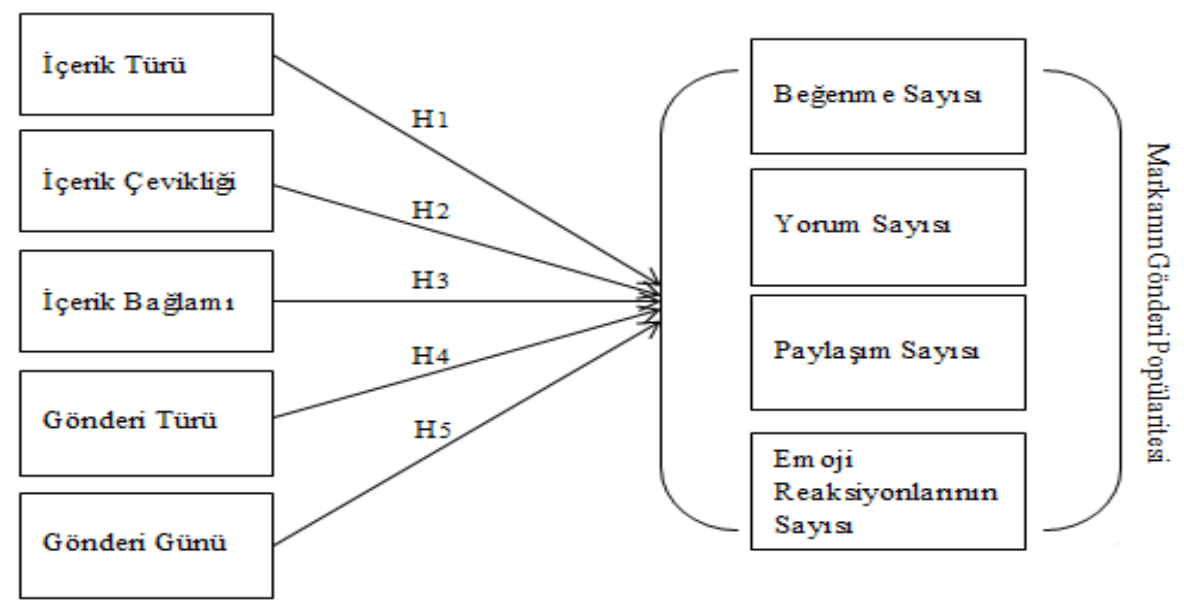

Şekil 1. Araştırma modeli

İçerik stratejisinin en önemli unsurlarından biri içerik türüdür. Bazı çalışmalar içerik türünü, bilgilendirici ve eğlenceli içerikler vb. olarak adlandırmıştır (De Vries ve diğ., 2012; Tafesse, 2015; Kormin ve Baharun, 2016). Bu çalışmada içerik türü metin, görsel içerik, video, bağlantı veya bunların bir kombinasyonu olarak adlandırılmıştır. Metin, görsel içerik, video 
ve/veya bağlantının kombinasyonu genellikle yapılan çalışmaların çoğu tarafından göz ardı edilmiştir. Çalışmalar; metin, görsel içerik, video, link vb. içeren içerik türünün, marka gönderi popülaritesi üzerinde farklı düzeylerde önemli bir etkiye sahip olduğunu göstermektedir (Chauhan ve Pillai, 2013; Sabate ve diğ., 2014; Kim ve Yang, 2017). Bu çerçevede, aşağ1daki hipotez önerilmiştir:

$H_{1}$ : İçerik türü ile marka gönderi popülaritesini belirleyen unsurlardan en az biri arasinda anlaml farklılık vardır.

Hedef kitlelerin marka gönderisine yönelik beğenileri, yorumları ve paylaşımları, gönderinin paylaşıldığı günün saatinden de etkilenir. Bu çalışmada gönderi paylaşım zamanlaması, içerik çevikliği olarak adlandırılmıştır. Gönderi paylaşım çizelgesini tasarlarken, müşterilerin ve/veya takipçilerin faaliyet saatleri ile ilgili alışkanlıklarını belirlemek çok önemlidir (Sabate ve diğ., 2014). Bu açıdan, aktif saatleri kullanarak markanın popülerliğini oluşturma ve arttırma olasılığı yüksektir. Dolayısıyla, aşağıdaki hipotez önerilmiştir:

$\mathrm{H}_{2}$ : Iç̧erik çevikliği ile marka gönderi popülaritesini belirleyen unsurlardan en az biri arasında anlaml farklılık vardır.

Marka gönderi konusunun; müşterilerin ve/veya takipçilerin gönderiye yönelik beğenisi, yorumu ve paylaşımı üzerinde etkisi olduğu düşünülmektedir. Bu çalışmada, marka gönderisinin konusu içerik bağlamı olarak adlandırılmıştır. Dolayısıyla, aşağıdaki hipotez önerilmiştir:

$H_{3}$ : Içerik bağlamı ile marka gönderi popülaritesini belirleyen unsurlardan en az biri arasında anlamlı farklılık vardır.

Sosyal medyada markalar, takipçileri ve ötesindekiler için kendi mesajlarını oluşturabilir. Ayrıca, başkaları tarafından oluşturulan içeriği de paylaşabilirler. Çalışmada, mesaj paylaşımındaki bu kaynak farklılığı gönderi türü olarak adlandırılmıştır. Kim ve Yang'ın (2017) çalışmasının sonucu, , marka tarafından oluşturulan mesajların marka gönderi popülerliğini, 
paylaşılan mesajlara kıyasla daha olumlu etkilediğini göstermiştir (Kim ve Yang, 2017). Bu açıdan, aşağıdaki hipotez önerilmiştir:

$H_{4}$ : Gönderi türü ile marka gönderi popülaritesini belirleyen unsurlardan en az biri arasinda anlamlı farklilık vardır.

İçeriğin takipçiler ve ötesindekiler ile paylaşıldığı gün gönderi günü olarak adlandırılmaktadır. Marka gönderi günü ile ilgili olarak gerçekleştirilen önceki çalışmalar sosyal medyada kullanıcı faaliyetlerinin çoğunun hafta içi gerçekleştirildiğini göstermektedir (Golder, Wilkinson ve Hubennan, 2007). Dolayısıyla, aşağıdaki hipotez önerilmiştir:

$H_{5}$ : Gönderi günü ile marka gönderi popülaritesini belirleyen unsurlardan en az biri arasında anlamlı farklilık vardır.

\section{Araştırmanın evreni ve örneklemi}

Yukarıda belirtilen hipotezleri test etmek için, çalışma Türkiye'deki bilişim şirketlerine odaklanmaktadır. Zaman ve maliyet konusundaki zorluklar nedeniyle, Türkiye'deki tüm bilişim şirketleri örnekleme dahil edilememiştir. Ayrıca, önde gelen bilişim şirketleri, markanın sayfalarındaki içerik stratejisine dayalı olarak daha etkin faaliyetler gerçekleştiriyor olabilir. Bu açıdan örneklem çerçevesi Türkiye'de önde gelen bilişim şirketleri olarak belirlenmiştir. Türkiye'de önde gelen bilişim şirketleri seçiminde "İlk 500 Bilişim Şirketi Türkiye 2017" araştırmasının sonuçları kullanılmıştır (www.hurriyet.com.tr). Belirlenen bu 500 bilişim şirketi arasinda tabakalı örnekleme yöntemi ile, donanım, hizmet ve yazılım alt kategorisinden tesadüfi olarak seçilen 9 bilişim şirketi örnekleme dahil edilmiştir. Sonuç olarak donanım alt kategorisinden PENTA Teknoloji, NETAŞ, Teknosa; hizmet alt kategorisinden Turkcell Global Bilgi, Koç Sistem, Türk Telekom; yazılım alt kategorisinden ise LOGO Yazılım, Innova Bilişim Çözümleri ve Intertech şirketleri çalışmanın örneklemini oluşturmuştur. 


\section{Veri toplama yöntemi}

Bilişim şirketlerinin sosyal medyada kullandığı içerik stratejisini ve marka gönderi popülaritesini belirlemeye yönelik olarak nitel veri toplama tekniklerinden faydalanılmış olup, verilerin sınıflandırılması ve karşılaştırılması için 'içerik analizi' kullanılmıştır. İçerik analizinin amacı, katılımcıların görüşlerinin ya da dokümanların sistematik bir şekilde tanımlanmasıdır (Altunışık ve diğ., 2010). İçerik analizinde, öncelikle sınıflama sistemi oluşturulmalıdır. Bu çalışmada marka gönderi popülaritesi; bir marka gönderisine ilişkin beğenilerin, yorumların, paylaşımların ve emoji reaksiyonlarının sayısıdır. Bu faktörler, sinıflama sistemi oluşturulurken kolayca ve ücretsiz olarak elde edilebilir (Bkz. Ek 1). Bu açıdan öncelikle şirketlerin sosyal medya kullanımları incelenmiştir.

Tablo 1. Bilişim Sektöründeki Markalarn Kullandıkları Sosyal Medya

\begin{tabular}{|c|c|c|c|c|c|c|c|c|c|}
\hline Sosyal Medya Türü & PENTA & NETAS & TEKNOSA & TURKCELL & KOC & TELEKOM & LOGO & INNOVA & INTERTECH \\
\hline Blog 1 & & $\mathrm{X}$ & & & $\mathrm{X}$ & & $\mathrm{X}$ & $\mathrm{X}$ & \\
\hline Microblog 2 & $\mathrm{X}$ & $\mathrm{X}$ & $\mathrm{X}$ & $\mathrm{X}$ & $\mathrm{X}$ & $\mathrm{X}$ & $\mathrm{X}$ & $\mathrm{X}$ & $\mathrm{X}$ \\
\hline $\begin{array}{l}\text { Profesyonel bağlant } \\
\text { sitelen }\end{array}$ & $\mathrm{X}$ & $\mathrm{X}$ & $\mathrm{X}$ & $\mathrm{X}$ & $\mathrm{X}$ & $\mathrm{X}$ & $\mathrm{X}$ & $\mathrm{X}$ & $\mathrm{X}$ \\
\hline Fotoğaf paylaşım ${ }^{3}$ & $\mathrm{X}$ & $\mathrm{X}$ & $\mathrm{X}$ & $\mathrm{X}$ & $\mathrm{X}$ & $\mathrm{X}$ & $\mathrm{X}$ & $\mathrm{X}$ & $\mathrm{X}$ \\
\hline \multicolumn{10}{|l|}{ Sanal dünya } \\
\hline Video paylaşım ${ }^{4}$ & $\mathrm{X}$ & $\mathrm{X}$ & $\mathrm{X}$ & $\mathrm{X}$ & $\mathrm{X}$ & $\mathrm{X}$ & $\mathrm{X}$ & $\mathrm{X}$ & $\mathrm{X}$ \\
\hline \multicolumn{10}{|l|}{ Sanal oyun } \\
\hline \multicolumn{10}{|l|}{ Sosyal işaretleme } \\
\hline Sosyal paylaşım ${ }^{5}$ & $\mathrm{X}$ & $\mathrm{X}$ & $\mathrm{X}$ & $\mathrm{X}$ & $\mathrm{X}$ & $\mathrm{X}$ & $\mathrm{X}$ & $\mathrm{X}$ & $\mathrm{X}$ \\
\hline Toplam & 5 & 6 & 5 & 5 & 6 & 5 & 6 & 6 & 5 \\
\hline
\end{tabular}

${ }^{1}$ Kunumsal blog ${ }^{2}$ Twitter ${ }^{3}$ Pinterest Instagram ${ }^{4}$ Youtube ${ }^{5}$ Facebook

Tablo 1'de görüldüğ ü gibi belirlenen şirketlerin tamamının microblogları, profesyonel bağlantı siteleri, fotoğraf paylaşım, video paylaşım ve sosyal paylaşım siteleri mevcuttur. Ancak sadece NETAŞ Koç Sistem, LOGO Yazılım ve Innova'nın kendine ait bloğu vardır. Bilişim şirketlerinin kurumsal web siteleri, sosyal medya kullanımları açısından incelenmiştir. Penta Teknoloji'nin kurumsal web sitesinin ana sayfasında sadece Facebook, Twitter ve LinkedIn'e ilişkin bağlantı mevcuttur, oysaki şirketin Instagram ve Youtube kanalı da vardır. NETAŞ'ın kullandığı sosyal medyanın bağlantılarının tamamı, kurumsal web sitesinin ana sayfasında mevcuttur. Sadece NETAŞ'ın bloğunun ana sayfada bağlantısı mevcut değildir. Teknosa da Pinterest hariç kullanılan sosyal medyanın tamamının 
ana sayfada bağlantısı mevcuttur. Turkcell Global Bilginin sadece Facebook, Google +, Twitter ve LinkedIn bağlantısı ana sayfadadır, oysaki şirketin Instagramı ve Youtube kanalı da mevcuttur. Koç Sistem'in kurumsal web sitesinin ana sayfasında ise sadece kurumsal bloğunun bağlantısı mevcuttur. Türk Telekom'un Pinterest hariç kullandığı sosyal medyanın bağlantılarının hepsi ana sayfasındadır. Benzer şekilde Logo Yazılım'ın kurumsal web sitesinin ana sayfasında, Instagram bağlantısı hariç kullandığı sosyal medyanın bağlantılarının hepsi mevcuttur. Innova Bilişim Çözümleri'nin ana sayfasında ise Instagram ve Pinterest hariç, diğerlerinin bağlantıları mevcuttur. Intertech'in kurumsal web sitesinde sadece Instagram'ın (intertech_it şeklindedir gösterimi) ana sayfada bağlantısı yoktur, kullandığı diğer sosyal medya bağlantılarının hepsi mevcuttur.

Verilerin hangi sosyal medyadan toplanacağı belirlenirken, en fazla kullanıldığı düşünülen Facebook, Twitter ve Instagram sayfaları üzerine yoğunlaşılmıştır. Belirlenen bilişim şirketlerine ait Facebook, Twitter ve Instagram sayfaları 1-31 Aralık 2018 tarihleri arasında bir ay süreyle izlenmiştir. Bu markaların sayfalarının takipçi ve gönderi sayıları Tablo 2'de görülmektedir.

Tablo 2. Sosyal medya takipçi ve gönderi sayıları

\begin{tabular}{|c|c|c|c|c|c|c|}
\hline IT Firmaları & $\begin{array}{c}\text { Facebook } \\
\text { Takipçi } \\
\text { Sayısı }\end{array}$ & $\begin{array}{c}\text { Facebook } \\
\text { Gönderi } \\
\text { Sayısı }\end{array}$ & $\begin{array}{c}\text { Twitter } \\
\text { Takipçi } \\
\text { Sayısı }\end{array}$ & $\begin{array}{c}\text { Twitter } \\
\text { Gönderi } \\
\text { Sayısı }\end{array}$ & $\begin{array}{c}\text { Instagram } \\
\text { Takipçi } \\
\text { Sayııı }\end{array}$ & $\begin{array}{c}\text { Instagram } \\
\text { Gönderi } \\
\text { Sayısı }\end{array}$ \\
\hline PENTA TEKNOLOJI & 45.876 & 15 & 3.929 & 15 & 984 & 15 \\
\hline NETAȘ & 18.767 & 12 & 11.868 & 23 & 1.348 & 13 \\
\hline TEKNOSA & 2.600 .564 & 29 & 593.891 & 49 & 228.218 & 8 \\
\hline $\begin{array}{l}\text { TURKCELL GLOBAL } \\
\text { BİGI }\end{array}$ & 21.406 & 11 & 6.156 & 10 & 2.385 & 10 \\
\hline KOC̣ SISTEM & 14.879 & 16 & 2.559 & 14 & 2.530 & 15 \\
\hline TÜRK TELEKOM & 3.354 .781 & 13 & 419.013 & 16 & 137.933 & 8 \\
\hline LOGO YAZILIM & 108.234 & 23 & 6.719 & 29 & 2.485 & 21 \\
\hline $\begin{array}{ll}\text { INNOVA } & \text { BİLISTíM } \\
\text { ÇÖZÜMLERİ } & \end{array}$ & 10.390 & 19 & 1.346 & 18 & 483 & 18 \\
\hline INTERTECH & 1.758 & 8 & 736 & 4 & 1.040 & 8 \\
\hline Toplam & 6.176 .655 & 146 & 1.046 .217 & 178 & 377.406 & 116 \\
\hline
\end{tabular}

Bilişim şirketleri bir ay boyunca toplam 178 Twitter, 146 Facebook ve 116 Instagram gönderisinde bulunmuşlardır. Ayrıca bu şirketlerin toplamda yaklaşık 6 milyon Facebook, yaklaşık 1 milyon Twitter ve yaklaşık 380 bin Instagram takipçileri vardır. Dolayısıyla takipçi ve gönderi sayısı daha az olan Instagram araştırma kapsamı dışında tutulmuş olup, veriler 
şirketlerin Facebook ve Twitter sayfaları üzerinden elde edilmiştir. Dolayısıyla toplamda 324 gönderiye ilişkin veri toplanmıştır.

Markanın gönderi popülaritesi; içerik türü, içerik çevikliği, içerik bağlamı, gönderi türü ve gönderi günü gibi faktörlere bağlı olabilir. Bu çalışmada, Chauhan ve Pillai'nin (2013) araştırmasına göre biraz değiştirilmiş 9 kategoride sınıflandırılmış içerik türü kullanılmıştır: metin, görsel içerik, video, bağlantı, metin + görsel içerik, metin + video, metin + bağlantı, metin + görsel içerik + link, metin + video + link. Diğer taraftan önerilen farklı zamansal kalıplar temelinde net bir uzlaşma yoktur (Chauhan ve Pillai, 2013; Sabate ve diğerleri, 2014). Bu çalışmada, içerik çevikliği, günün 24 saatini her biri 6 saat aralığına bölen 4 bölüm olarak adlandırılmış ve gönderiler buna göre kodlanmıştır (00-06, 06-12, 12-18, 18-24). Tafesse ve Wien (2017) ile Chauhan ve Pillai'nin (2013) araştırmasına dayanarak yedi kategoriye ayrılan içerik bağlamı değişkeni kullanılmıştır: Şirket ile ilgili içerikler, Ürün/kampanya ile ilgili içerikler, bilişim /ülke/iş ile ilgili içerikler, Çalışanlar ile ilgili içerikler, Eğitim ile ilgili içerikler, ödül/motivasyon vb. toplantıları/ etkinlik/ anma ve kutlamalar, Diğer (belirlenen altı kategori dışında kalan içerik konusu bu başlık altında kodlanmıştır). Kim ve Yang'ın (2017) çalışmasına dayanarak, markanın gönderi türü iki kategoride gruplandırılmıştır: oluşturulan ve paylaşılan. Son olarak gönderi

günü, Sabate ve diğerlerinin (2014) çalışmasına dayanarak hafta içi ve hafta sonu olmak üzere iki kategoriye ayrılmıştır.

\section{Verilerin Analizi ve Bulgular}

Öncelikle verilerin güvenilirliği değerlendiriciler arası güvenilirlik ile test edilmiştir. Değerlendirici (intercoder) güvenilirliği, bağımsız değerlendiricilerin içerik özelliklerinin değerlendirilmesinde aynı kodlama kararını verme derecesini ölçer (Lombard ve diğ. 2002). Araştırmacının öznel değerlendirmelerinin etkisini ortadan kaldırmak için değerlendirme sürecine bir lisansüstü öğrencisi katılmıştır. Güvenilirlik analiz sonuçlarına göre, Cronbach Alfa değeri yaklaşık \%91'dir. Dolayısıyla veri setinin güvenilirliği çok yüksektir. Belirlenen bilişim şirketleri tarafından paylaşılan toplam 324 içeriğe yönelik, marka gönderi popülaritesini belirleyen unsurlara ait sonuçlar Tablo 3'de görülmektedir. 
Tablo 3'de görüldüğü gibi Facebook ve Twitter'da marka gönderi popülaritesi açısından en fazla kullanılan unsur 'Beğeni'dir. Facebook içeriklerinin, toplam gönderi sayısı daha az olmasına rağmen daha fazla ‘Beğeni' aldığ1 görülmektedir. Bu durum; Facebook takipçi sayısının daha fazla olmasından kaynaklanıyor olabilir.

Tablo 3. Marka gönderi popülaritesi

\begin{tabular}{|c|c|c|c|c|c|c|c|}
\hline IT Firmaları & \multicolumn{4}{|c|}{ Facebook } & \multicolumn{3}{|c|}{ Twitter } \\
\hline & Beğeni & Yorum & Paylașım & Emoji & Beğeni & Yorum & Paylașım \\
\hline PENTA TEKNOLOJI & 140 & 2 & 14 & - & 63 & 3 & 18 \\
\hline NETAȘ & 206 & 4 & 23 & 4 & 3086 & 30 & 107 \\
\hline TEKNOSA & 4.180 & 326 & 209 & 152 & 5.169 & 895 & 504 \\
\hline TURKCELL GLOBAL BİGI & 325 & 45 & 113 & 93 & 171 & 1 & 57 \\
\hline KOC̣ SISTEM & 325 & 2 & 26 & 1 & 112 & 0 & 40 \\
\hline TÜRK TELEKOM & 6.174 & 5.564 & 417 & 2.536 & 4525 & 4150 & 590 \\
\hline LOGO YAZILIM & 306 & 10 & 98 & 20 & 212 & 7 & 33 \\
\hline INNOVA BÍLIȘIM ÇÖZÜMLERI & 7.288 & 22 & 61 & 40 & 48 & 0 & 5 \\
\hline INTERTECH & 284 & 0 & 14 & 7 & 39 & 0 & 1 \\
\hline Toplam & 19.228 & 5.975 & 975 & 2853 & 13.425 & 5.086 & 1.355 \\
\hline
\end{tabular}

Diğer taraftan Facebook'ta da Twitter'da da marka gönderi popülaritesi açısından takipçiler tarafından en az kullanılan unsur 'Paylaşım'dır. Twitter' da toplam takipçi sayısı daha az olmasına rağmen, Facebook'a k1yasla daha fazla paylaşım gerçekleştirilmiştir. Bu durum, Twitter'da toplamda sunulan gönderi sayısının daha fazla olması ve/veya Twitter'ın doğasından kaynaklanan paylaşıma yatkınlık ile açılanabilir. Facebook'ta bulunan emoji reaksiyonları unsuru hala çok fazla kullanılmaktadır. Görüldüğ̈̈ gibi Türk Telekom haricinde diğer şirketlerin gönderilerine yönelik emoji reaksiyonları çok az seviyededir. Türk Telekom'da ise en fazla emoji reaksiyonlarını, belirli bir ulusal konuya ilişkin (örn. limitsiz internet) içerikler almıştır. Marka gönderi popülaritesini belirleyen unsurların tamamına baktığımızda ise, Facebook içeriklerinin daha yüksek gönderi popülaritesi olduğu görülmektedir.

Facebook'ta en fazla beğeni alan içerik; 2.215 beğeni ile Innova Bilişim Çözümlerinin Facebook sayfasına ait içeriktir, ayrıca karşılaşılan tek İngilizce içeriktir. Twitter' da en fazla beğeni alan içerik, NETAŞ'ın 2.513 beğeni alan İstanbul Havalimanı ile ilgili gönderi içeriğidir. Türk Telekom'a ait limitsiz interneti ifade eden bir içerik, 1.646 yorum ile en fazla yorum 
alan Facebook içeriği olmuştur. Bu içerik aynı zamanda, 137 kez paylaşılmiş ve en fazla paylaşılan Facebook içeriği olmuştur. Twitter'da en fazla yorum alan içerik ise, Türk Telekom'un 1.617 yorum alan internette sinırların kalktığını ifade eden içeriktir. Twitter' da en fazla paylaşılan içerik ise 258 kez paylaşılan Teknosa'nın 'Anlatsam Film Olur' kampanyasına aittir. Son olarak en fazla emoji reaksiyonunu, 731 tane emoji alarak 'Türkiye'nin interneti Türk Telekom internette sınırları kaldırıyor' başlığında limitsiz internete geçişi aktaran içerik almıştır. Facebook ve Twitter'a yönelik içerik türü sonuçları ise Tablo 4 'te görülmektedir.

Tablo 4. İçerik türü sonuçları

\begin{tabular}{|c|c|c|c|c|c|c|c|c|c|}
\hline Içerik Türü & PENTA & NETAȘ & TEKNOSA & TURKCELL & KOÇ & TELEKOM & LOGO & INNOVA & INTERTECH \\
\hline \multicolumn{10}{|l|}{ Facebook } \\
\hline Metin & - & - & - & - & - & - & - & - & - \\
\hline Görsel içerik & $1(0.7)$ & - & - & $3(2.1)$ & - & - & - & - & $1(0.7)$ \\
\hline Video & - & - & - & - & - & - & - & $1(0.7)$ & $1(0.7)$ \\
\hline Bağlant & - & - & - & - & - & - & - & - & - \\
\hline Metin+Görsel içerik & $11(7.5)$ & $6(4.1)$ & $2(1.4)$ & $8(5.5)$ & $9(6.2)$ & $6(4.1)$ & $5(3.4)$ & $4(2.7)$ & $5(3.4)$ \\
\hline Metim+Video & - & $3(2.1)$ & $6(4.1)$ & - & $4(2.7)$ & - & $7(4.8)$ & $1(0.7)$ & $1(0.7)$ \\
\hline Metin+Bağlanth & - & - & $1(0.7)$ & - & - & $1(0.7)$ & - & - & - \\
\hline Metin+Görsel içerik+Baglantı & $2(1.4)$ & $3(2.1)$ & $4(2.7)$ & - & $1(0.7)$ & $3(2.1)$ & $5(3.4)$ & $13(8.9)$ & - \\
\hline Metin+Video+Bağlant & $1(0.7)$ & - & $16(11.0)$ & - & $2(1.4)$ & $3(2.1)$ & $6(4.1)$ & - & - \\
\hline \multicolumn{10}{|l|}{ Twitter } \\
\hline Metin & - & $6(3.4)$ & $9(5.1)$ & - & - & - & $2(1.1)$ & - & - \\
\hline Görsel içerik & - & - & - & $3(1.7)$ & - & - & - & - & $2(1.1)$ \\
\hline Video & - & - & - & - & - & - & - & - & - \\
\hline Bağlant & - & 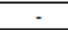 & - & - & - & - & - & - & - \\
\hline Metim+Görsel içerik & $12(6.7)$ & $10(5.6)$ & $2(1.1)$ & $7(3.9)$ & $8(4.5)$ & $6(3.4)$ & $7(3.9)$ & $2(1.1)$ & $2(1.1)$ \\
\hline Metin+Video & - & $3(1.7)$ & $13(7.3)$ & - & $3(1.7)$ & - & $8(4.5)$ & $1(0.6)$ & - \\
\hline Metin+Bağlanth & - & $2(1.1)$ & $8(4.5)$ & - & - & $1(0.6)$ & $5(2.8)$ & - & - \\
\hline Metin+Görsel içerik+Bgg̣antu & $2(1.1)$ & $2(1.1)$ & $3(1.7)$ & - & $1(0.6)$ & $4(2.2)$ & $3(1.7)$ & $15(8.4)$ & - \\
\hline Metin+Video+Bağlant & $1(0.6)$ & - & $14(7.9)$ & - & $2(1.1)$ & $5(2.8)$ & $4(2.2)$ & - & - \\
\hline
\end{tabular}

Bilişim şirketleri tarafından, izlenen süre boyunca Facebook'ta sadece 'Metin' ve sadece 'Bağlantı' içeriği hiç kullanılmamıştır. Aynı şirketler, Twitter'da sadece 'Video' ve sadece 'Bağlantı' içeriğini hiç kullanmamışlardır. Facebook'ta, Twitter'da ve dolayısıyla toplamda en fazla kullanılan içerik yaklaşık \%35'lik oran ile 'Metin+Görsel içerik' tir. Facebook'ta en az kullanılan içerikler, yaklaşık \%1'lik oran ile sadece 'Video' ve 'Metin+Bağlantı' içeriğidir. Twitter' da ise en az kullanılan içerik yaklaşık \%3'lük oran ile 'Görsel içerik'tir. İzlenen süre boyunca Facebook'ta da Twitter'da da en fazla içerik paylaşan IT şirketi ise Teknosa' dır. Teknosa Facebook'ta 29, Twitter' da 49 olmak üzere toplamda bir aylık süre boyunca 78 içerik paylaşmıştır. Teknosa'nın paylaştığı toplam içeriğin yaklaşık \%38'i ise 'Metin+Video+Bağlantı' içeriğidir ve hem Facebook'ta hem de Twitter'da en 
çok bu içerik türünü kullanmıştır. İzlenen süre boyunca Facebook'ta da Twitter'da da en az içerik paylaşan bilişim şirketi ise Intertech olmuştur. Intertech Facebook'ta 8, Twitter'da 4 olmak üzere toplamda bir aylık süre boyunca 12 içerik paylaşmıştır. PENTA Teknoloji, NETAŞ, Turkcell Global Bilgi, Koç Sistem, Türk Telekom ve Intertech şirketleri gönderilerinde en fazla 'Metin+Görsel içerik'i kullanmıştır. LOGO Yazılım en fazla 'Metin+Video' içeriğini, Innova Bilişim Çözümleri ise en fazla 'Metin+Görsel içerik+Bağlantı' türünü kullanmıştır. Facebook ve Twitter'a yönelik içerik çevikliği sonuçları ise Tablo 5'te görülmektedir.

Tablo 5. İçerik çevikliği sonuçları

\begin{tabular}{|c|c|c|c|c|c|c|c|c|c|}
\hline Içerik Cevikliği & PENTA & NETAS & TEKNOSA & TURKCELI & KOÇ & TELEKOM & LOGO & INNOVA & INTERTECH \\
\hline \multicolumn{10}{|l|}{ Facebook } \\
\hline $00.01-06.00$ & & & $1(0.7)$ & $1(0.7)$ & & - & $2(1.4)$ & - & \\
\hline $06.01-12.00$ & $2(1.4)$ & $7(4.8)$ & $8(5.5)$ & $5(3.4)$ & $11(7.5)$ & $6(4.1)$ & $6(4.1)$ & $8(5.5)$ & $2(1.4)$ \\
\hline $12.01-18.00$ & $13(8.9)$ & $5(3.4)$ & $15(10.3)$ & $5(3.4)$ & $5(3.4)$ & $6(4.1)$ & $15(10.3)$ & $9(6.2)$ & $6(4.1)$ \\
\hline $18.01-24.00$ & - & - & $5(3.4)$ & - & - & $1(0.7)$ & $\cdot$ & $2(1.4)$ & - \\
\hline \multicolumn{10}{|l|}{ Twitter } \\
\hline $00.01-06.00$ & - & . & . & - & - & - & - & - & - \\
\hline $06.01-12.00$ & $1(0.6)$ & $5(2.8)$ & $13(7.3)$ & $4(2.2)$ & $4(2.2)$ & $3(1.7)$ & $2(1.1)$ & $4(2.2)$ & $2(1.1)$ \\
\hline $12.01-18.00$ & $14(7.9)$ & $16(9.0)$ & $24(13.5)$ & $4(2.2)$ & $8(4.5)$ & $10(5.6)$ & $24(13.5)$ & $14(7.9)$ & $2(1.1)$ \\
\hline $18.01-24.00$ & & $2(1.1)$ & $12(6.7)$ & $2(1.1)$ & $2(1.1)$ & $3(1.7)$ & $3(1.7)$ & & \\
\hline
\end{tabular}

Bilişim şirketleri tarafından, izlenen süre boyunca Twitter'da 00.0106.00 saatlerinde hiç paylaşım yapılmamıştır. Ancak aynı şirketlerden Teknosa ve Turkcell Global Bilgi'nin Facebook'da 1'er, LOGO Yazılım'ın ise 2 gönderi paylaştığ 1 görülmektedir. Bu durum bu şirketlerin, sosyal medyayı bir bütünsel olarak değil ayrı ayrı mecralar olarak gördükleri ve bu şekilde içerik stratejilerini yönlendirdikleri fikrini oluşturmaktadır. Facebook'ta, Twitter'da ve dolayısıyla toplamda en fazla kullanılan içerik gönderim saati yaklaşık \%60'lık oran ile 12.01-18.00 aralığıdır. Facebook'ta en az kullanılan zaman dilimi yaklaşık \%3'lük oran ile 00.01-06.00 aralığıken, Twitter'da en az kullanılan zaman dilimi \%13.5'lik oran ile 18.0124.00 aralığıdır. İzlenen süre boyunca PENTA Teknoloji, NETAŞ, Teknosa, Türk Telekom, LOGO Yazılım, Innova Bilişim Çözümleri ve Intertech sosyal medya paylaşımlarında en fazla 12.01-18.00 saat dilimini kullanmıştır. Koç Sistem ise paylaşımlarında en fazla 06.01-12.00 saatleri arasını kullanmıştır. Turkcell Global Bilgi ise paylaştığı içeriklerin yaklaşık \%43'ünü 06.01-12.00 saatleri arasında, aynı şekilde yaklaşı \%43'ünü ise 
12.01-18.00 saatleri arasında sunmuştur. Facebook ve Twitter'a yönelik içerik bağlamı sonuçları ise Tablo 6' da görülmektedir. Bilişim şirketleri tarafından, izlenen süre boyunca hem Facebook'ta hem de Twitter'da Bilişim/Ülke/İş ile ilgili hiç paylaşım yapılmamıştır. Ayrıca aynı şirketler Facebook'ta belirlenen konular dişında kalan ve 'Diğer' olarak nitelendirilebilecek bir paylaşımda da bulunmamışlardır.

Tablo 6. İçerik bağlamı sonuçları

\begin{tabular}{|c|c|c|c|c|c|c|c|c|c|}
\hline Içerik Bağlamı & PENTA & NETAȘ & TEKNOSA & TURKCELL & KOC̣ & TELEKOM & LOGO & INNOVA & INTERTECH \\
\hline \multicolumn{10}{|l|}{ Facebook } \\
\hline Şirket & $3(2.1)$ & $6(4.1)$ & $3(2.1)$ & $2(1.4)$ & $6(4.1)$ & $1(0.7)$ & $10(6.8)$ & $1(0.7)$ & $2(1.4)$ \\
\hline Urün/kampanya & $9(6.2)$ & - & $19(13.0)$ & $5(3.4)$ & $3(2.1)$ & $8(5.5)$ & $7(4.8)$ & $13(8.9)$ & - \\
\hline IT/U1ke/15 & - & - & - & - & - & - & - & - & - \\
\hline Çalı̨̧anlar & - & $1(0.7)$ & - & $1(0.7)$ & $1(0.7)$ & - & $1(0.7)$ & - & $1(0.7)$ \\
\hline Esitim & $2(1.4)$ & - & $1(0.7)$ & - & - & - & - & - & - \\
\hline $\begin{array}{l}\text { Odillmotivasyon vb. } \\
\text { toplantlar/ etkinlik/ } \\
\text { anma ve kutlamalar }\end{array}$ & $1(0.7)$ & $5(3.4)$ & $6(4.1)$ & $3(2.1)$ & $6(4.1)$ & $4(2.7)$ & $5(3.4)$ & $5(3.4)$ & $5(3.4)$ \\
\hline Diger & - & - & - & - & - & - & - & - & - \\
\hline \multicolumn{10}{|l|}{ Twitter } \\
\hline Şirket & $2(1.1)$ & $8(4.5)$ & $3(1.7)$ & $1(0.6)$ & $3(1.7)$ & $2(1.1)$ & $12(6.7)$ & $2(1.1)$ & - \\
\hline Urün/kampanya & $9(5.1)$ & $6(3.4)$ & $25(14.0)$ & $5(2.8)$ & $4(2.2)$ & $8(4.5)$ & $9(5.1)$ & $12(6.7)$ & - \\
\hline IT/U1ke/1ş & - & - & - & - & - & - & - & - & - \\
\hline Çalışanlar & - & $3(1.7)$ & - & $1(0.6)$ & $1(0.6)$ & - & $2(1.1)$ & - & $1(0.6)$ \\
\hline Egitim & $2(1.1)$ & $1(0.6)$ & - & - & - & - & - & - & - \\
\hline $\begin{array}{l}\text { Oduil/motivasyon vb. } \\
\text { toplantlar/ etkinlik/ } \\
\text { anma ve kutlamalar }\end{array}$ & $2(1.1)$ & $5(2.8)$ & $8(4.5)$ & $3(1.7)$ & $6(3.4)$ & $6(3.4)$ & $6(3.4)$ & $4(2.2)$ & $3(1.7)$ \\
\hline Diger & - & - & $13(7.3)$ & - & - & - & - & - & - \\
\hline
\end{tabular}

Tablo 6'da görüldügü gibi Facebook'ta, Twitter'da ve dolayısıyla toplamda en fazla kullanılan içerik yaklaşı \%44'lük oran ile ürün ve/veya kampanyalarla ilgili içeriklerdir. Aynı şekilde Facebook'ta, Twitter'da ve dolayısıyla toplamda en az kullanılan içerik bağlamı ise \%2'lik oran ile eğitim ile ilgili konulardır. İzlenen süre boyunca PENTA Teknoloji, Teknosa, Turkcell Global Bilgi, Türk Telekom ve Innova Bilişim Çözümleri sosyal medyada en fazla ürün ve/veya kampanyalarla ilgili içerikler paylaşmışlardır. NETAŞ ve LOGO Yazılım ise paylaşımlarında en fazla şirketleriyle ilgili konuları ele almışlardır. Son olarak Koç Sistem ve Intertech şirketleri en fazla ödül, motivasyon vb. toplantılar, etkinlikler, anma ve kutlamalar ile ilgili içerikler paylaşmışlardır. Facebook ve Twitter'a yönelik gönderi türü sonuçları ise Tablo 7'de görülmektedir. 
Tablo 7. Gönderi türü sonuçları

\begin{tabular}{|c|c|c|c|c|c|c|c|c|c|}
\hline Gönderi Türü & PENTA & NETAȘ & TEKNOSA & TURKCELL & KOC & TELEKOM & LOGO & \begin{tabular}{l|} 
INNOVA \\
\end{tabular} & INTERTECH \\
\hline \multicolumn{10}{|l|}{ Facebook } \\
\hline Oluşturulan & $14(9.6)$ & $12(8.2)$ & $26(17.8)$ & $11(7.5)$ & $14(9.6)$ & $8(5.5)$ & $23(15.8)$ & 19(13.0) & $8(5.5)$ \\
\hline Paylaşilan & $1(0.7)$ & - & $3(2.1)$ & . & $2(1.4)$ & $5(3.4)$ & - & - & - \\
\hline \multicolumn{10}{|l|}{ Twitter } \\
\hline Oluşturulan & $14(7.9)$ & $21(11.8)$ & $47(26.4)$ & $10(5.6)$ & $13(7.3)$ & $7(3.9)$ & $29(16.3)$ & 18(10.1) & $4(2.2)$ \\
\hline Paylaşılan & $1(0.6)$ & $2(1.1)$ & $2(1.1)$ & - & $1(0.6)$ & $9(5.1)$ & - & - & - \\
\hline
\end{tabular}

Bilişim şirketleri tarafından, izlenen süre boyunca hem Facebook'ta hem de Twitter'da ve dolayısıyla toplamda en fazla kullanılan gönderi türü yaklaşık \%92'lik oran ile şirketlerin kendileri tarafından oluşturulan içeriklerdir. Yaklaşık \%8'lik oran ile şirketler diğerleri tarafından daha önce oluşturulmuş ve paylaşılmış içerikleri tekrar paylaşmışlardır. PENTA Teknoloji, NETAŞ, Teknosa, Turkcell Global Bilgi, Koç Sistem, Türk Telekom, LOGO Yazılım, Innova Bilişim Çözümleri ve Intertech şirketlerinin tamamı en fazla kendilerinin oluşturduğu içerikleri paylaşmışlardır. Aynı zamanda izlenen süre boyunca hem Facebook'ta hem Twitter'da Turkcell Global Bilgi, LOGO Yazılım, Innova Bilişim Çözümleri ve Intertech şirketleri paylaşılan içerik sunmamışlardır. NETAŞ ise Facebook sayfasında paylaşılan içerik sunmamıştır. Facebook ve Twitter'a yönelik gönderi günü sonuçları ise Tablo 8'de görülmektedir.

Tablo 8. Gönderi günü sonuçları

\begin{tabular}{|l|c|c|c|c|c|c|c|c|c|}
\hline Gönderi Günü & PENTA & NETAȘ & TEKNOSA & TURKCELL & KOC̣ & TELEK0M & LOG0 & INNOVA & INTERTECH \\
\hline Facebook \\
\hline Hafta içi & $12(8.2)$ & $11(7.5)$ & $26(17.8)$ & $10(6.8)$ & $16(11.0)$ & $13(8.9)$ & $22(15.1)$ & $18(12.3)$ & $6(4.1)$ \\
\hline Hafta sonu & $3(2.1)$ & $1(0.7)$ & $3(2.1)$ & $1(0.7)$ & - & - & $1(0.7)$ & $1(0.7)$ & $2(1.4)$ \\
\hline Twitter & $12(6.7)$ & $21(11.8)$ & $34(19.1)$ & $9(5.1)$ & $13(7.3)$ & $16(9.0)$ & $28(15.7)$ & $17(9.6)$ & $4(2.2)$ \\
\hline Hafta içi & $3(1.7)$ & $2(1.1)$ & $15(8.4)$ & $1(0.6)$ & $1(0.6)$ & - & $1(0.6)$ & $1(0.6)$ & - \\
\hline Hafta sonu &
\end{tabular}

Bilişim şirketleri tarafından, izlenen süre boyunca hem Facebook'ta hem de Twitter'da ve dolayısıyla toplamda en fazla kullanılan gönderi günü yaklaşık \%89'luk oran ile hafta içidir. Yaklaşık \%11'lik oran ile şirketler hafta sonları içerik paylaşmışlardır. PENTA Teknoloji, NETAŞ, Teknosa, Turkcell Global Bilgi, Koç Sistem, Türk Telekom, LOGO Yazılım, Innova Bilişim Çözümleri ve Intertech şirketlerinin tamamı en fazla hafta içi 
gönderi paylaşmıştır. Türk Telekom izlenen süre boyunca hem Facebook'ta hem Twitter'da hafta sonu içerik paylaşmamıştır. Koç Sistem Facebook'ta, Intertech ise Twitter'da hafta sonu içerik paylaşmamıştır.

Bilişim şirketlerinin sosyal medyada kullandığı içerik stratejisi ve marka gönderi popülaritesi arasında farklılık olup olmadığını saptamak üzere geliştirilen hipotezleri test etmek için öncelikle verilerin normal dağılıp dağılmadığı incelenmiştir. Bu açıdan, marka gönderi popülaritesini belirleyen unsurlar üzerine gerçekleştirilen normallik analizi sonuçları Tablo 9' da görülmektedir.

Tablo 9. Normallik analizi sonuçları

\begin{tabular}{|c|c|c|c|c|}
\hline \multirow{2}{*}{$\begin{array}{l}\text { Marka Gönderi } \\
\text { Popülaritesini } \\
\text { Belirleyen Unsurlar }\end{array}$} & \multicolumn{2}{|c|}{ Facebook } & \multicolumn{2}{|c|}{ Twitter } \\
\hline & Shapiro-Wilk & Anlamlllık Düzeyi $(\mathrm{P})^{*}$ & Shapiro-Wilk & Anlamlllık Düzeyi $(\mathrm{P})^{*}$ \\
\hline Beğenme & 0.439 & 0.000 & 0.227 & 0.000 \\
\hline Yorum & 0.236 & 0.000 & 0.193 & 0.000 \\
\hline Paylaşım & 0.392 & 0.000 & 0.274 & 0.000 \\
\hline Emoji Reaksiyonları & 0.192 & 0.000 & - & - \\
\hline
\end{tabular}

'Tüm p-değerleri $<0.05$ 'dir.

Normallik analizi sonucunda, Shapiro-Wilk testi sonuçları hem Facebook hem de Twitter için bütün marka gönderi popülaritesini belirleyen unsurlar açısından ileri düzeyde (p: 0.000) anlamlılık göstermiştir. Dolayısıyla hiçbir unsur için normallik varsayımı sağlanmamıştır. Ayrıca önceli tablolarda görüldüğü gibi gruplar bazında varyanslar açısından homojen bir dağılım da yoktur. Bu nedenle, hipotezlerin testinde parametrik olmayan testlerin kullanılmasına karar verilmiştir. Bu durumda, iki grubu karşılaştırmak için Mann Whitney U (parametrik olmayan bağımsız iki örneklem testi) kullanılırken; ikiden fazla grubu karşılaştırmak için Kruskal Wallis H (k bağımsız örneklem testi) kullanılmıştır. Öncelikle bilişim şirketlerinin sosyal medyada kullandığ 1 içerik stratejisi ve marka gönderi popülaritesi arasında farklılık olup olmadığını topluca görmek için, \%95 güven düzeyinde gerçekleştirilen analizlerden elde edilen anlamlılık düzeylerinin tamamı Tablo 10'da sunulmuştur. Buna göre, çalışmanın H1, H2 ve H3 hipotezlerini test edilmesi için Kruskal Wallis H testi gerçekleştirilmiş ve elde edilen sonuçlar Tablo 10'da görülmektedir. Çalışmanın H4 ve $\mathrm{H} 5$ hipotezlerini test edilmesi için Mann Whitney $\mathrm{U}$ testi gerçekleştirilmiştir ve elde edilen sonuçlar Tablo 10'da görülmektedir. 
Tablo 10. Kruskal Wallis H ve Mann Whitney U testi sonuçlarn

\begin{tabular}{|l|c|c|c|c|c|c|c|}
\hline İçerik Stratejileri & \multicolumn{5}{|c|}{ Facebook } & \multicolumn{3}{c|}{ Twitter } \\
\hline & Beğeni & Yorum & Paylașı & Emoji & Beğeni & Yorum & Paylașım \\
\hline İçerik Türü & $0.033^{*}$ & $0.001^{*}$ & $0.012^{*}$ & $0.001^{*}$ & $0.000^{*}$ & $0.001^{*}$ & $0.043^{*}$ \\
\hline İçerik Çeviklĭği & $0.033^{*}$ & $0.028^{*}$ & 0.237 & $0.019^{*}$ & $0.000^{*}$ & $0.029^{*}$ & $0.000^{*}$ \\
\hline İçerik Bağlam1 & 0.102 & 0.080 & 0.179 & 0.336 & $0.000^{*}$ & 0.306 & 0.107 \\
\hline Gönderi Türü & 0.108 & $0.009^{*}$ & 0.952 & 0.058 & $0.001^{*}$ & $0.000^{*}$ & $0.000^{*}$ \\
\hline Gönderi Günü & 0.437 & 0.721 & 0.743 & 0.937 & 0.100 & 0.814 & 0.389 \\
\hline
\end{tabular}

"p-değeri $<0.05$

Hipotez testleri sonucunda, hem Facebook hem de Twitter için $\mathrm{H}_{1}, \mathrm{H}_{2}$ ve $\mathrm{H}_{4}$ kabul edilirken $\mathrm{H}_{5}$ red edilmiştir. $\mathrm{H}_{3}$ Facebook için red edilirken, Twitter açısından $\mathrm{H} 3$ kabul edilmiştir. Çünkü Twitter'da içerik bağlamı ve marka gönderi popülaritesini belirleyen unsurlarından 'Beğeni' arasında anlamlı farklılık (p: 0.000) vardır. H1 çerçevesinde değerlendirme yapıldığında, hem Facebook hem de Twitter için içerik türü ile marka gönderi popülaritesini belirleyen unsurların tamamında anlamlı farklılık oluşmuştur. Dolayısıyla Facebook'ta içerik türü ile 'Beğeni', 'Yorum', 'Paylaşım' ve 'Emoji' reaksiyonları arasında; Twitter' da 'Beğeni', 'Yorum' ve 'Paylaşım' arasında anlamlı farklılık vardır. H2 çerçevesinde değerlendirme yapıldığında, Facebook'ta içerik çevikliği ile 'Beğeni', 'Yorum' ve 'Emoji' reaksiyonları arasında; Twitter' da ise 'Beğeni', 'Yorum' ve 'Paylaşım' arasında anlamlı farklılık vardır. $\mathrm{H} 4$ çerçevesinde değerlendirme yapıldığında, Twitter'da gönderi türü ile marka gönderi popülaritesini belirleyen unsurların tamamı arasında anlamlı farklılık vardır. Facebook'ta ise gönderi türü ile sadece 'Yorum' arasında anlamlı farklılık vardır. Son olarak, her iki sosyal mecrada gönderi günü ile marka gönderi popülaritesini belirleyen unsurlar arasında istatistiki olarak anlamlı bir farklılık görülmemiştir.

Kruskal Wallis H Testi sonucunda anlamlı farklılık olduğu görülen durumlarda, farklıı̆ı̆ın hangi grup(lar)dan kaynaklandığını anlamak için tamamlayıcı Post-Hoc testlerinden Dunn's Pairwise testi tercih edilmiştir. Sadece istatistiki olarak anlamlılık oluşan hipotezlere ilişkin ki-kare değeri, grup farklılıklarının anlamlılık düzeyi ve sıra ortalamaları ilgili tablolarda sunulmuştur. Dolayısıyla ilk olarak içerik türü ile marka gönderi popülaritesini belirleyen unsurlara yönelik sonuçlar Tablo 11'de görülmektedir. 
Tablo 11'de görüldüğ̈̈ gibi Facebook' ta 'Metin+Görsel içerik+Bağlantı' ve 'Metin+Video+Bağlantı' türündeki içerikler, 'Metin+Görsel içerik' türünden daha fazla beğeni almaktadır. Benzer şekilde 'Metin+Görsel içerik+Bağlantı' ve 'Metin+Video+Bağlantı' türündeki içerikler, 'Metin+Video' içerik türünden daha fazla beğeni almaktadır.

Tablo 11. İçerik türü-marka gönderi popülaritesi sonuçları

\begin{tabular}{|c|c|c|c|c|c|c|c|c|}
\hline \multirow{2}{*}{$\begin{array}{l}\text { Marka Gönderi } \\
\text { Popülaritesini } \\
\text { Belirleyen Unsurlar }\end{array}$} & \multicolumn{4}{|c|}{ Facebook } & \multicolumn{4}{|c|}{ Twitter } \\
\hline & $\chi^{2}$ & Gruplar & $\mathrm{P}^{*}$ & Sira Ort. & $\chi^{2}$ & Gruplar & $\mathrm{P}^{*}$ & Sira Ort. \\
\hline Beğeni & 13.737 & $\begin{array}{l}5-8 \\
5-9 \\
6-8 \\
6-9\end{array}$ & $\begin{array}{l}0.031 \\
0.009 \\
0.049 \\
0.019\end{array}$ & $\begin{array}{l}5=63.18 \\
6=60.36 \\
8=83.60 \\
9=88.59\end{array}$ & 28.450 & $\begin{array}{l}5-6 \\
5-9 \\
7-6 \\
8-1 \\
8-6 \\
8-9\end{array}$ & $\begin{array}{l}0.002 \\
0.005 \\
0.041 \\
0.023 \\
0.000 \\
0.000\end{array}$ & $\begin{array}{c}1=92.94 \\
5=80.15 \\
6=117.45 \\
7=84.47 \\
8=57.52 \\
9=114.60\end{array}$ \\
\hline Yorum & 22.078 & $\begin{array}{l}5-7 \\
5-9 \\
6-7 \\
6-9 \\
8-9\end{array}$ & $\begin{array}{l}0.022 \\
0.000 \\
0.042 \\
0.004 \\
0.010\end{array}$ & $\begin{array}{l}5=61.45 \\
6=67.30 \\
7=125.50 \\
8=73.27 \\
9=99.34\end{array}$ & 24.063 & $\begin{array}{l}2-6 \\
2-9 \\
5-6 \\
5-9 \\
7-9 \\
8-6 \\
8-9\end{array}$ & $\begin{array}{l}0.041 \\
0.017 \\
0.003 \\
0.000 \\
0.018 \\
0.004 \\
0.001\end{array}$ & $\begin{array}{c}2=63.00 \\
5=76.93 \\
6=109.18 \\
7=82.38 \\
8=74.32 \\
9=117.58\end{array}$ \\
\hline Paylaşım & 16.389 & $\begin{array}{l}5-6 \\
5-8 \\
5-9\end{array}$ & $\begin{array}{l}0.043 \\
0.009 \\
0.000\end{array}$ & $\begin{array}{l}5=56.95 \\
6=78.25 \\
8=81.40 \\
9=92.75\end{array}$ & 12.983 & $\begin{array}{l}5-9 \\
8-6 \\
8-9\end{array}$ & $\begin{array}{l}0.039 \\
0.011 \\
0.003\end{array}$ & $\begin{array}{c}5=85.46 \\
6=103.18 \\
8=69.35 \\
9=110.19\end{array}$ \\
\hline Emoji & 22.028 & $\begin{array}{l}2-9 \\
5-8 \\
5-9 \\
6-9 \\
8-9\end{array}$ & $\begin{array}{l}0.026 \\
0.045 \\
0.000 \\
0.006 \\
0.042\end{array}$ & $\begin{array}{l}2=56.40 \\
5=60.42 \\
6=68.52 \\
8=78.29 \\
9=99.41\end{array}$ & & & & \\
\hline
\end{tabular}

'Tüm p-değerleri $<0.05$ 'dir.

Tablo 11'de görüldüğü gibi ‘Metin+Bağlantı' ve 'Metin+Video+Bağlantı' türündeki içerikler, 'Metin+Görsel içerik' türünden daha fazla yorum almaktadır. Benzer şekilde 'Metin+Bağlantı' ve 'Metin+Video+Bağlantı' türündeki içerikler, 'Metin+Video' içerik türünden daha fazla yorum almaktadır. Ayrıca 'Metin+Video+Bağlantı' türündeki içerikler, 'Metin+Görsel içerik+Bağlantı' türündekilere kıyasla daha fazla yorum almaktadır. Diğer taraftan 'Metin+Video', 'Metin+Görsel içerik+Bağlantı' ve 'Metin+Video+Bağlantı' türündeki içerikler, 'Metin+Görsel içerik' türünden daha fazla paylaşılmaktadır. Son olarak 'Metin+Video+Bağlantı' türündeki içerikler, 'Görsel içerik' türünden daha fazla emoji reaksiyonu al- 
maktadır. 'Metin+Görsel içerik+Bağlantı' ve 'Metin+Video+Bağlantı' türündeki içerikler, 'Metin+Görsel içerik' türünden daha fazla emoji reaksiyonu almaktadır. 'Metin+Video+Bağlantı' türündeki içerikler, 'Metin+Video' içerik türünden daha fazla emoji reaksiyonu almaktadır. 'Metin+Video+Bağlantı' türündeki içerikler, 'Metin+Görsel içerik+Bağlantı' türünden daha fazla emoji reaksiyonu almaktadır. Dolayısıyla Facebook' ta 'Metin+Video+Bağlantı' türündeki içeriklerin beğeni, yorum, paylaşım ve emoji reaksiyonunu daha fazla alma temelinde üstünlügü dikkat çekmektedir.

Twitter'da 'Metin+Video' ve 'Metin+Video+Bağlantı' türündeki içerikler, 'Metin+Görsel içerik' türünden daha fazla beğeni almaktadır. 'Metin+Video' içerik türü, 'Metin+Bağlantı' içerik türünden daha fazla beğeni almaktadır. 'Metin', 'Metin+Video' ve 'Metin+Video+Bağlantı' türündeki içerikler, 'Metin+Görsel içerik+Bağlantı' türünden daha fazla beğeni almaktadır. 'Metin+Video' ve 'Metin+Video+Bağlantı' türündeki içerikler, 'Görsel içerik' türüne kıyasla daha fazla yorum almaktadır. Benzer şekilde 'Metin+Video' ve 'Metin+Video+Bağlantı' türündeki içerikler, 'Metin+Görsel içerik' türünden daha fazla yorum almaktadır. 'Metin+Video+Bağlantı' türündeki içerikler, 'Metin+Bağlantı' içerik türünden daha fazla yorum almaktadır. Ayrıca 'Metin+Video' ve 'Metin+Video+Bağlantı' türündeki içerikler, 'Metin+Görsel içerik+Bağlantı' türünden daha fazla yorum almaktadır. Son olarak 'Metin+Video+Bağlantı' türündeki içerikler, 'Metin+Görsel içerik' türünden daha fazla paylaşılmaktadır. 'Metin+Video' ve 'Metin+Video+Bağlantı' türündeki içerikler, 'Metin+Görsel içerik+Bağlantı' tütüne kıyasla daha fazla paylaşılmaktadır. Dolayısıyla Twitter' da 'Metin+Video' ve 'Metin+Video+Bağlantı' türündeki içeriklerin beğeni, yorum ve paylaşım alma temelinde üstünlüğü dikkat çekmektedir. İçerik çevikliği ile marka gönderi popülaritesini belirleyen unsurlara yönelik sonuçlar Tablo 12' de görülmektedir.

Facebook'ta 18.01-24.00 saatleri arasında gönderi paylaşmak, 00.0106.00 saatleri arasında gönderi paylaşmaya kıyasla daha fazla beğeni almaktadır. Benzer şekilde 18.01-24.00 saatleri arasında gönderi paylaşmak, zaman dilimi olarak 06.01-12.00 ve 12.01-18.00 arasını kullanmaya kıyasla daha fazla beğeni almaktadır. 18.01-24.00 saatleri arasında gönderi paylaşmak, 06.01-12.00 ve 12.01-18.00 saatleri arasında gönderi paylaşmaya kıyasla daha fazla yorum almaktadır. Benzer şekilde 18.01-24.00 saatleri 
arasında gönderi paylaşmak, gönderi zaman dilimi olarak 06.01-12.00 ve 12.01-18.00 arasinı kullanmaya kiyasla daha fazla emoji reaksiyonu almaktadır. Dolayısıyla Facebook'ta gönderi zaman dilimi olarak 18.0124.00 saatleri arasını kullanmanın, beğeni, yorum ve emoji reaksiyonunu daha fazla alma temelinde üstünlügü dikkat çekmektedir.

Tablo 12. İçerik çevikliği-marka gönderi popülaritesi sonuçları

\begin{tabular}{|c|c|c|c|c|c|c|c|c|}
\hline \multirow{2}{*}{$\begin{array}{l}\text { Marka Gönderi } \\
\text { Popülaritesini } \\
\text { Belirleyen Unsurlar }\end{array}$} & \multicolumn{4}{|c|}{ Facebook } & \multicolumn{4}{|c|}{ Twitter } \\
\hline & $\chi^{2}$ & Gruplar & $\mathrm{P}^{*}$ & Sira Ort. & $\chi^{2}$ & Gruplar & $\mathrm{P}^{*}$ & Sura Ort. \\
\hline Beğeni & 8.730 & $\begin{array}{l}1-4 \\
2-4 \\
3-4\end{array}$ & $\begin{array}{l}0.023 \\
0.008 \\
0.005\end{array}$ & $\begin{array}{c}1=56.25 \\
2=72.42 \\
3=70.92 \\
4=115.06\end{array}$ & 20.185 & $\begin{array}{l}3-2 \\
3-4\end{array}$ & $\begin{array}{l}0.001 \\
0.000\end{array}$ & $\begin{array}{c}2=108.80 \\
3=77.02 \\
4=119.27\end{array}$ \\
\hline Yorum & 9.085 & $\begin{array}{l}2-4 \\
3-4\end{array}$ & $\begin{array}{l}0.007 \\
0.003\end{array}$ & $\begin{array}{l}2=73.20 \\
3=69.72 \\
4=113.06\end{array}$ & 7.092 & $\begin{array}{l}2-4 \\
3-4\end{array}$ & $\begin{array}{l}0.048 \\
0.008\end{array}$ & $\begin{array}{l}2=88.71 \\
3=84.94 \\
4=112.77\end{array}$ \\
\hline Paylaşm & & & & & 15.814 & $\begin{array}{l}3-2 \\
3-4\end{array}$ & $\begin{array}{l}0.008 \\
0.001\end{array}$ & $\begin{array}{l}2=103.87 \\
3=78.91 \\
4=117.94\end{array}$ \\
\hline Emoji & 9.972 & $\begin{array}{l}2-4 \\
3-4\end{array}$ & $\begin{array}{l}0.002 \\
0.004\end{array}$ & $\begin{array}{l}2=67.95 \\
3=72.80 \\
4=115.06\end{array}$ & & & & \\
\hline
\end{tabular}

*Tüm p-değerleri $<0.05$ 'dir.

Twitter'da 06.01-12.00 ve 18.01-24.00 saatleri arasında gönderi paylaşmak, 12.01-18.00 saatleri arasında gönderi paylaşmaya kıyasla daha fazla beğeni almaktadır. Gönderi zaman dilimi olarak 18.01-24.00 saatleri arasinı kullanmak, 06.01-12.00 ve 12.01-18.00 saatleri arasında gönderi paylaşmaya kıyasla daha fazla yorum almaktadır. Gönderi zaman dilimi olarak 06.01-12.00 ve 18.01-24.00 saatleri arasını kullanmak 12.01-18.00 saatleri arasını kullanmaya kıyasla daha fazla paylaşım almaktadır. Dolayısiyla Twitter'da gönderi zaman dilimi olarak 06.01-12.00 ve $18.01-24.00$ saatleri arasını kullanmanın, beğeni ve paylaşımı daha fazla alma temelinde üstünlüğü dikkat çekmektedir. Son olarak Twitter'da gönderi zaman dilimi olarak 18.01-24.00 saatleri arasını kullanmanın, yorumu daha fazla alma temelinde üstünlüğü dikkat çekmektedir. İçerik bağlamı ile marka gönderi popülaritesini belirleyen unsurlara yönelik sonuçlar Tablo 13'de görülmektedir. 
Tablo 13. İçerik bă̆lamı-beğeni sonuçları

\begin{tabular}{|l|c|l|l|l|}
\hline Marka Gönderi & \multicolumn{4}{|c|}{ Twitter } \\
\cline { 2 - 5 } $\begin{array}{l}\text { Popülaritesini } \\
\text { Belirleyen Unsurlar }\end{array}$ & $\mathbf{X}$ & Gruplar & $P^{*}$ & Srra Ort. \\
\hline Beğeni & 22.207 & $1-6$ & 0.001 & $1=65.50$ \\
& & $1-7$ & 0.000 & $2=85.80$ \\
& & $2-6$ & 0.036 & $4=73.94$ \\
& & $2-7$ & 0.003 & $6=106.34$ \\
& & $4-7$ & 0.013 & $7=131.69$ \\
\hline
\end{tabular}

*Türm p-değerleri < 0.05'dir.

Twitter'da ödül/motivasyon vb. toplantıları/ etkinlik/ anma ve kutlamalar ile belirlenen bağlamlar dişında kalan 'Diğer' konular, 'Şirket' ile ilgili konulara kıyasla daha fazla beğeni almaktadır. Benzer şekilde ödül/motivasyon vb. toplantıları/ etkinlik/ anma ve kutlamalar ile belirlenen bağlamlar dişında kalan 'Diğer' konular, 'Ürün/Kampanya' ile ilgili konulara kıyasla daha fazla beğeni almaktadır. Son olarak belirlenen bağlamlar dışında kalan 'Diğer' konular, 'Çalışanlar' ile ilgili konulardan daha fazla beğeni almaktadır. Dolayısıyla Twitter' da ödül/motivasyon vb. toplantıları/ etkinlik/ anma ve kutlamalar ile belirlenen bağlamlar dışında kalan 'Diğer' konuların Twitter'da daha fazla beğeni alma temelinde üstünlüğü dikkat çekmektedir. Gönderi türü ile marka gönderi popülaritesini belirleyen unsurlara yönelik sonuçlar Tablo 14' de görülmektedir.

Tablo 14. Gönderi türü-marka gönderi popülaritesi sonuçlarn

\begin{tabular}{|l|c|c|c|c|c|c|c|c|}
\hline Marka Gönderi & \multicolumn{5}{|c|}{ Facebook } & \multicolumn{4}{c|}{ Twitter } \\
\cline { 2 - 8 } $\begin{array}{l}\text { Popülaritesini } \\
\text { Belirleyen Unsurlar }\end{array}$ & $\chi^{\mathbf{2}}$ & Gruplar & $\mathbf{P}^{*}$ & Srra Ort. & $\boldsymbol{\chi 2}$ & Gruplar & $\mathbf{P}^{*}$ & Sra Ort. \\
\hline Beğeni & & & & & 1869.5 & $1-2$ & 0.001 & $\begin{array}{c}1=85.53 \\
2=132.63\end{array}$ \\
\hline Yorum & 1064.0 & $1-2$ & 0.009 & $\begin{array}{c}1=71.12 \\
2=102.73\end{array}$ & 1869.0 & $1-2$ & 0.000 & $\begin{array}{c}1=85.53 \\
2=132.60\end{array}$ \\
\hline Paylaşm & & & & & 2030.5 & $1-2$ & 0.000 & $\begin{array}{c}1=84.54 \\
2=143.37\end{array}$ \\
\hline
\end{tabular}

'Tüm p-değerleri $<0.05$ 'dir.

Facebook'ta gönderi türü ile marka gönderi popülaritesini belirleyen unsurlardan sadece yorum arasında anlamlı farklılık oluşmuştur. Facebook'ta paylaşılan gönderiler, marka tarafından oluşturulan gönderilerden daha fazla yorum almaktadır. Twitter'da da benzer şekilde paylaşılan gönderiler, marka tarafından oluşturulan gönderilerden daha fazla yorum almaktadır. Aynı zamanda Twitter'da paylaşılan gönderiler, marka tarafından oluşturulan gönderilerden hem daha fazla beğeni hem de daha fazla paylaşım almaktadır. 


\section{Sonuç ve Öneriler}

Türkiye'de bilişim sektörü dünyadaki teknolojik gelişmelere paralel olarak hızla büyümektedir. Teknolojiyi etkili bir şekilde kullanmayı gerektiren bu faaliyet alanında, şirketlerin marka stratejisi geliştirmeleri rekabet avantajı elde etmede elzem hale gelmiştir. Sosyal medyanın markalaşma stratejilerinden faydalanmak bilişim sektörü için kayda değer bir potansiyel vaat etmektedir. Şirketlerin sosyal medya hesaplarındaki paylaşımlar iç ve dış paydaşları ile etkileşim kurma açısından önemli bir araçtır. Bu nedenle, sosyal medyadaki paylaşımlar için benimsenen içerik stratejisi marka gönderi popülaritesi oluşturmak ve geliştirmek için önemlidir. Bu bağlamda çalışmanın amacı, bilişim şirketlerinin sosyal medyada kullandığı içerik stratejisi ve marka gönderi popülaritesi arasında farklılık olup olmadığını ortaya koymaktır.

Çalışmada içerik stratejileri; içerik, içerik çevikliği, içerik bağlamı, gönderi türü ve gönderi günü kapsamında ele alınmıştır. Marka gönderi popülaritesini belirleyen unsurlar ise beğenme, yorum, paylaşım ve emoji reaksiyonları sayısı olarak ele alınmıştır. Belirlenen amaca ulaşmak için bilişim sektöründen 9 şirket (PENTA Teknoloji, NETAŞ, Teknosa, Turkcell Global Bilgi, Koç Sistem, Türk Telekom, LOGO Yazılım, Innova Bilişim Çözümleri ve Intertech şirketleri) seçilmiştir. Seçilen şirketlerin Facebook ve Twitter sayfalarından, 1-31 Aralık 2018 tarihleri arasında toplamda 324 gönderi kaydedilmiştir. Bu gönderiler hipotezleri test etmek için analize tabii tutulmuştur. Kruskal Wallis $\mathrm{H}$ ve Mann Whitney U testleri sonucunda $\mathrm{H}_{1}, \mathrm{H}_{2}$ ve $\mathrm{H}_{4}$ kabul edilmiş, $\mathrm{H}_{5}$ ise reddedilmiştir. İçerik bağlamı ile marka gönderi popülaritesini belirleyen unsurlardan en az biri arasında anlamlı farklılık vardır şeklindeki H3 hipotezi ise Facebook kapsamında red edilirken, Twitter için ise kabul edilmiştir. Twitter'da içerik bağlamı ve marka gönderi popülaritesini belirleyen unsurlardan 'Beğeni' arasında anlamlı farklılık bulunmuştur.

İçerik türü ile marka gönderi popülaritesini belirleyen unsurlar $(\mathrm{H} 1)$ çerçevesinde elde edilen sonuçlar Tafesse (2015) ile Srivastava ve diğerlerinin (2018) çalışmalarının sonuçları benzerlik göstermektedir. Diğer taraftan bilişim sektörünün hem Facebook'ta hem de Twitter'da ve dolay1sıyla toplamda en fazla kullandığı içerik 'Metin+Görsel içerik'tir. Araş- 
tırma sonucunda ise Facebook'ta 'Metin+Video+Bağlantı' türündeki içeriklerin beğeni, yorum, paylaşım ve emoji reaksiyonunu daha fazla aldığ1 görülmüştür. Benzer şekilde Twitter'da 'Metin+Video' ve 'Metin+Video+Bağlantı' türündeki içeriklerin daha fazla beğeni, yorum ve paylaşım aldığı görülmüştür. Dolayısıyla bilişim şirketleri tarafından sıklıkla kullanılan içerik türü ile araştırma sonucu elde edilen ve marka gönderi popülaritesi oluşturma kapasitesi daha yüksek olan içerik türleri arasında farklılık oluşmuştur. Sabate ve diğerlerinin (2014) çalışması, içerik çevikliğinin marka gönderi popülaritesini belirleyen unsurlardan $\left(\mathrm{H}_{2}\right)$ sadece yorum üzerinde etkisi olduğunu göstermiştir. Elde edilen sonuçlar bir dereceye kadar çalışmanın sonuçları ile benzerlik göstermektedir. Belirlenen şirketlerin Facebook'ta, Twitter'da ve dolayısıyla toplamda en fazla kullanıldığ 1 içerik gönderim saati 12.01-18.00 aralığıdır. Oysaki Facebook'ta gönderi zaman dilimi olarak 18.01-24.00 saatleri arasını kullanmak, beğeni, yorum ve emoji reaksiyonunu daha fazla çekmektedir. Ayrıca Twitter' da gönderi zaman dilimi olarak 06.01-12.00 ve 18.01-24.00 saatleri arasını kullanmak, beğeni ve paylaşımı daha fazla çekmektedir. Son olarak Twitter'da gönderi zaman dilimi olarak 18.01-24.00 saatleri arasını kullanmak, yorumu içeriğe daha fazla çekmektedir. Dolayısıyla bilişim şirketleri tarafından sıklıkla kullanılan içerik gönderim zamanı ile araştırma sonucu elde edilen ve marka gönderi popülaritesi oluşturma kapasitesi daha yüksek olan zaman dilimleri arasında da farklılık oluşmuştur. İçerik bağlamı ile marka gönderi popülaritesini belirleyen unsurlar $\left(\mathrm{H}_{3}\right)$ çerçevesinde elde edilen sonuçlar, Chauhan ve Pillai'nin araştırmasının sonuçları (2013) ile benzerlik göstermektedir. Çünkü Chauhan ve Pillai'nin araştırması Facebook temelinde gerçekleştirilmiştir ve mevcut çalışmanın sonuçlarına göre de $\mathrm{H} 3$ Facebook için red edilmiştir. Ancak H3 Twitter temelinde kabul edilmiştir. Bu durumdan da açıkça anlaşılacağı gibi her bir sosyal mecranın, marka gönderi popülaritesi oluşturma açısından kenine has bir yapısı vardır. Twitter' da en fazla kullanılan içerik ürün ve/veya kampanyalarla ilgili içeriklerdir. Oysaki Twitter'da ödül/motivasyon vb. toplantılarl/ etkinlik/ anma ve kutlamalar ile belirlenen bağlamlar dışında kalan 'Diğer' konuların Twitter'da daha fazla beğeni alma potansiyeli vardır. Dolayısıyla bilişim şirketleri tarafından Twitter'da sıklıkla kullanılan içerik bağlamı ile araştırma sonucu elde edilen ve marka gönderi popülaritesi oluşturma kapasitesi daha yüksek olan bağlamlar arasında da farklılık oluşmuştur. H4 
kapsamında ise Kim ve Yang (2017) ile benzer sonuçlar elde edilmemiştir. Bu durum farklı bir sektöre odaklanmaktan, farklı ülkelerde uygulamanın gerçekleşmesinden ya da ilgili çalışmasının sadece Facebook a odaklanmasından kaynaklanıyor olabilir. Çalışmanın sonuçlarına göre, bilişim şirketlerinin hem Facebook'ta hem de Twitter'da ve dolayısıyla toplamda en fazla kullanılan gönderi türü şirketlerin kendileri tarafından oluşturulan içeriklerdir. Oysaki Facebook'ta paylaşılan gönderiler, marka tarafından oluşturulan gönderilerden daha fazla yorum almaktadır. Twitter'da ise paylaşılan gönderiler, marka tarafından oluşturulan gönderilere k1yasla daha fazla beğeni, yorum ve paylaşım almaktadır. Dolayısıyla bilişim şirketleri tarafından kullanılan gönderi türü ile araştırma sonucu elde edilen ve marka gönderi popülaritesi oluşturma kapasitesi daha yüksek olan gönderi türü arasında da farklılık oluşmuştur. Son olarak gönderi günü ile ilgili sonuçlar (H5), Sabate ve diğerlerinin (2014) çalışmasının sonuçları ile benzerlik göstermektedir. $\mathrm{H}_{1}, \mathrm{H} 2$, H3 ve $\mathrm{H}_{4}$ kapsamında şirketlerin sosyal medyadaki uygulamaları ile analiz sonucu elde edilen bilgiler arasında yukarıda bahsedildiği gibi farklılıklar oluşmuştur. Bilişim sektöründeki dijital pazarlamadan sorumlu uzmanların, oluşan bu farklılıklara odaklanmaları gerekmektedir. Böylece sosyal medyada bilişim şirketleri daha popüler içerikler sunmuş ve daha fazla takipçi ve ötesindekilerin ilgisini çekmiş olurlar. Ayrıca belirlenen unsurlara her bir sosyal mecra temelinde farklı farklı eğilerek şirketler, sosyal medyada müşteri ilişkileri oluşturma ve geliştirme, marka hakkında görünürlük oluşturma ve bilgi sunma, markaya yönelik pozitif tutumlar oluşturma vb. olumlu çıtılar elde edebilirler.

Çalışmadan elde edilen sonuçlar Facebook ve Twitter'da takipçilerin farklı davranış kalıpları ve farklı reaksiyonları olduğunu da gözler önüne sermektedir. Bu kapsamda her iki mecrayı karşılaştırma olanağı veren mevcut çalışma özgündür. Dolayısıyla her bir sosyal mecranın kendine has bir yapısı olduğu ve bu çerçevede değerlendirilmesi gerektiği açıtır. Şirketlerdeki dijital pazarlama uzmanlarının her bir sosyal mecra için ayrı ayrı içerik stratejisi geliştirerek, marka gönderi popülaritesini artırmaya odaklanmaları gerekmektedir. Böylece sosyal medyada markanın görünürlüğünün artırılması, daha fazla takipçi oluşturulması vb. olumlu çıktılar elde edilebilir. Ayrıca çalışma kapsamında güncel bir konu olan emoji reaksiyonları da değerlendirilmiştir. İlgili değerlendirmeyi modele alan 
çalışma sayısı kısıtlı olduğundan bu çerçevede de mevcut çalışma özgündür. Ancak emoji reaksiyonları açısından yapılan değerlendir4meler, bu reaksiyonların pozitif ya da negatif olması ve/veya bu durumun etkilerini göz ardı etmiştir ve sadece sayılarına odaklamıştır. Çalışmanın çeşitli kısıtlılıkları vardır. Öncelikle bilişim sektöründen sadece 9 şirketin sosyal medyada kullandıkları içerik stratejilerine odaklanılmıştır. Bu çerçevede daha fazla şirketin çalışma kapsamına alınması genelleme yapmak açısından önerilebilir. Ayrıca çalışma şirketlerin sadece bir aylık Facebook ve Twitter verilerine odaklanmıştır. Bu çerçevede daha uzun bir zaman dilimini kapsayan dönemler seçilmesi önerilebilir. İleriki çalışmalar emoji reaksiyonların pozitif ya da negatif olması ve/veya bu durumun etkileri temelinde gerçekleştirilebilir. Ayrıca ileriki çalışmalar, içerik stratejilerinin marka gönderi popülaritesi üzerindeki çoklu etkisine odaklanabilir ve kontrol değişkeni olarak takipçi sayısı, gönderinin uzunluğu vb. değişkenleri kullanabilir. Son olarak farklı kültürlerde ve farklı sektörlerde gerçekleştirilecek çalışmalar, sonuçların karşılaştırılmasına olanak sağlayabilir. 
EXTENDED ABSTRACT

\title{
The Role of Content Strategy on Brand Post's Popularity in Social Media: A Research on IT Firms in Turkey \\ *
}

\author{
Dilek Penpece Demirer - Elife Özer
}

Adana Alparslan Türkeş ScienceETechnology University

IT market in Turkey has improved sharply over the last decade. In 2011 with 49.2 billion TL Turkey IT market size reached 116.9 billion TL in 2017 (the www.karel.com.tr). Brands in such a fast-growing sector also feel the pressure to adopt a brand strategy. Integrating social media with IT sector branding strategy offers a great potential for IT companies. The social media page of a brand can perform a bridge function with the followers and beyond. Internal and external stakeholders can be encouraged to interact with a brand submission. Therefore, the content strategy adopted is important to create and develop a brand post popularity. Different strategies that used for the content of the posts may create differences on the post popularity. In this context, the aim of this study is to examine the role of the content strategy on brand post popularity used by information tecnology companies in social media.

\section{Research Hypotheses}

The following hypotheses were aimed to be tested in the context of the study:

H1: There is a significant difference between at least one of the factors determining the content type and brand post's popularity.

$\mathrm{H} 2$ : There is a significant difference between content agility and at least one of the factors determining brand post's popularity.

H3: There is a significant difference between the content context and at least one of the factors determining brand post's popularity.

H4: There is a significant difference between at least one of the factors determining the type of post's and brand post's popularity. 
H5: There is a significant difference between at least one of the factors determining the posting day and brand post's popularity.

\section{Sample}

To test the hypothesis above, the study focuses on the information technology companies in Turkey. Due to difficulties in time and cost, all IT companies in Turkey could not be included in the sample. The sampling frame has been identified as the leading IT companies in Turkey. "Top 500 IT Companies in Turkey in 2017" list has been used (on website www.hurriyet.com.tr) and among these 500 companies, nine IT companies were randomly selected from the hardware, service and software sub-categories with stratified sampling method.

\section{Data collection}

Qualitative data collection techniques have been utilized to determine the content strategy and brand post's popularity on social media. Brand post's popularity in the study is determined by; the number of likes, comments, shares and emoji reactions of a brand post. These factors can be obtained easily and free of charge when creating a classification system (see Annex $1)$.

While determining the social media platforms to collect the data, the most popular social platforms were focused on: Facebook, Twitter and Instagram. Facebook, Twitter and Instagram pages of the selected IT companies were followed for one month between the dates of 1 and 31 December, 2018. Instagram has the least followers and number of posts. For this reason, the data has been obtained from Facebook and Twitter pages of the companies and their Instagram pages are excluded from the data collection process. Final data consisted of 324 Facebook and Twitter posts in total.

\section{Data analysis and findings}

The study was carried out to examine the role of the content strategy on the brand post's popularity in social media by examining the information 
technology companies in Turkey. The sample consists of nine IT companies from hardware, software and services sub-categories and their social media (Facebook and Twitter) posts have been studied. The content strategies in the study was represented by the content type, content agility, content context, posting type and posting day. The factors determining the brand post's popularity were evaluated as the number of likes, comments, shares and emoji reactions.

According to the results of reliability analysis, Cronbach's Alpha value is approximately $91 \%$. Therefore, the reliability of the data set is very high. The most common content type on Facebook and Twitter is Text + Visual content with a rate of $35 \%$. The most frequent posts were sent by Facebook and Twitter are the 12.01-18.00 hours range with a $60 \%$ ratio. The most common posting day by the IT companies were in weekdays, $89 \%$.

As a result of the hypothesis testing, both $\mathrm{H} 1, \mathrm{H} 2$ and $\mathrm{H} 4$ were accepted for both Facebook and Twitter, while H5 was rejected. H3 has been accepted for Twitter however, it has been rejected for Facebook. Therefore the findings suggest that content type, content agility and posting type differ significantly over the brand post's popularity. The results of the study also show that social media followers have different behaviors and different reactions among Facebook and Twitter. Digital marketing professionals of companies are adviced to focus on enhancing brand post's popularity by developing a separate content strategy for each social media platform.

In the context of the study, comparison of Facebook and Twitter posts and the evaluation of emoji reactions are among the factors that make the study original. Besides, the findings should be evaluated considering that only nine IT Company's social media posts were examined in the context of the study. Thefore, for the future studies in the field, it can be suggested to enlarge the sample size in the scope of work to be able the compare the results.

\section{Kaynakça / References}

Alexa Analitic, (2017). The top 500 sites on the web http://www.alexa.com/topsites, Retrieved July 3, 2017. 
Altunışık, R., Coşkun R, Bayraktaroğlu S. ve Yıldırım E. (2010). Sosyal bilimlerde araştırma yöntemleri SPSS uygulamalı, 6. Bask1, İstanbul: Sakarya Yayıncilik.

Aydın, İ. (2012). Bilişim sektörü ve Türkiye'nin sektördeki potansiyeli. International Journal of New Trends in Arts, Sports \& Science Education (IJTASE), 1(1), 180-200.

Bagozzi, R. P., ve Dholakia U. M. (2002). Intentional social action in virtual communities. Journal of Interactive Marketing, 16(2), 2-21.

Ceci, F., ve Prencipe, A. (2008). Configuring capabilities for integrated solutions: evidence from the IT sector. Industry and Innovation, 15(3), 277-296.

Chauhan, K., ve Pillai, A. (2013). Role of content strategy in social media brand communities: A case of higher education institutes in India. Journal of Product and Brand Management, 22(1), 40-51.

Chiang, C. H. Ve Tseng, K. C. (2017). The Influence of Fan Pages on Consumer Purchase Intention: Liking Behavior as a Moderator. Journal of Marketing Management, 5(2), 44-59.

Cho M., Schweickart, T., ve Haase A. (2014). Public engagement with nonprofit organizations on Facebook. Public Relations Review, 40(3), 565-567.

Chua A. Y. K., ve Banerjee S. (2015). Marketing via social networking sites: A study of brand-post popularity for brands in Singapore. Proceedings of The International MultiConference of Engineers and Computer Scientists (IMECS), 363-368, Hong Kong.

Cova B., ve Pace S. (2006). Brand community of convenience products: New forms of customer empowerment - the case 'My Nutella The Community. European Journal of Marketing, 40(9-10), 1087-1105.

Culnan, M. J., McHugh, P. J., ve Zubillaga, J. I. (2010). How large US companies can use Twitter and other social media to gain business value. MIS Quarterly Executive, 9(4), 243-259.

De Vries L., Gensler S., ve Leeflang Peter S. H. (2012). Popularity of brand posts on brand fan pages: An investigation of the effects of social media marketing. Journal of Interactive Marketing, 26(2), 83-91.

Ellison N. B., Steinfield C. ve Lampe, C. (2011). Connection strategies: Social capital implications of facebook-enabled communication practices. New Media \& Society, 13(6), 873-892. 
Greenwood S., Perrin A., ve Duggan M. (2016). Social media update 2016. file:///C:/Users/pc/Downloads/PI_2016.11.11_Social-Media-Update_FINAL.pdf, Erişim Tarihi: 6 Temmuz 2017.

Golder, S. A., Wilkinson, D. M., \& Hubennan, B. A. (2007). Rhythms of social interaction: Messaging within a massive online network. In Proceedings of the 3rd Communities and Technologies Conference, $C$ and $T$ 2007. https://doi.org/10.1007/978-1-84628-905-7_3

Kaur W., Balakrishnan V., Rana O. ve Sinniah A. (2018). Liking, sharing, commenting and reacting on Facebook: User behaviors' impact on sentiment intensity. Telematics and Informatics, https://www.sciencedirect.com/science/article/abs/pii/S0736585318304325 , Erişim tarihi: Aralık 28, 2018.

Kietzmann J. H., Hermkens K., McCarthy I. P., ve Silvestre B. S. (2011). Social Media? Get Serious! Understanding the functional building blocks of social media. Business Horizons, 54(3), 241-251.

Kim C., ve Yang S-U. (2017). Like, comment, and share on Facebook: How each behavior differs from the other. Public Relations Review, 43(2), 441-449.

Kormin, K., ve Baharun, R. (2016). Social media and relationship marketing strategies of Malaysian car brands. Indian Journal of Science and Technology, 9(46), 1-8.

Lehmann W. S. (2015). The influence of electronic word-of-mouth (EWom) on collage search and choice, Doctoral Thesis, University of Miami.

Lipsman A., Mudd G., Rich M., ve Bruich S. (2012). The power of like: How brands reach (and influence) fans through social-media marketing. Journal of Advertising Research, 52(1), 40-52.

Lombard M., Synder-Duch, J. ve Bracken, C. C. (2002). Content analysis in mass communication: Assessment and reporting intercoder reliability. Human Communication Research, 28(4), 587-604.

McAlexander J. H., Schouten J. W., ve Koenig H. F. (2002). Building brand community. Journal of Marketing, 66(1), 38-54.

McKinsey Quarterly, Eylül 2009 raporu, https://www.mckinsey.-com/business-functions/digital-mckinsey/our-insights/how-companiesare-benefiting-from-web-20-mckinsey-global-survey-results , Erişim tarihi: 1 Ocak 2019. 
Muntinga D. G., Moorman M., ve Smit E. G. (2011). Introducing COBRAs: Exploring motivations for brand-related social media use. International Journal of Advertising, 30(1), 13-46.

Palazón M., Sicilia M., ve López M. (2015). The influence of 'facebook friends' on the intention to join brand pages. Journal of Product and Brand Management, 24(6), 580-595.

Peng K-F., Fan Y-W., ve Hsu T-A. (2004). Proposing the content perception theory for online content industry - a structural modeling. Industrial Management \& Data Systems, 104(6), 469-489.

Penpece D. (2013). Dijital içerik pazarlaması. Adana: Karahan Kitabevi.

Perrin, A. (2015). Social media usage. Pew research center, 52-68.

Sabate F., Berbegal-Mirabent J., Cañabate A. ve Lebherz P. R. (2014). Factors influencing popularity of branded content in facebook fan pages. European Management Journal, 32(6), 1001-1011.

Srivastava, J., Saks, J., Weed, A. J. ve Atkins, A. (2018). Engaging audiences on social media: Identifying relationships between message factors and user engagement on the American Cancer Society's Facebook page. Telematics and Informatics, 35(7), 1832-1844.

Smith C. (2017). By the Numbers: 90 Imazing Facebook Page Statistics (May 2017), http://expandedramblings.com/index.php/facebookpage-statistics/, Retrieved July 4, 2017.

Sprout Social Survey, (2017). https://sproutsocial.com/insights/data/q12017/, Erişim Tarihi: Ocak 5, 2018.

Tafesse W. (2015). Content strategies and audience response on facebook brand pages. Marketing Intelligence \& Planning, 33(6), 927-943.

Tafesse, W. ve Wien, A. (2017). A framework for categorizing social media posts. Cogent Business and Management, 4, 1-22.

Trefzger T. F., Baccarella C. V., ve Voigt K-I. (2016). Antecedents of brand post popularity in facebook: The influence of images, videos, and text", Proceedings of the 15th International Marketing Trends Conference, 1-8. Venice.

We Are Social, (2018) Digital report, -https://wearesocial.com/us/blog/2018/01/global-digital-report-2018, Erişim tarihi: 30 Ocak 2019.

Whisman R. (2009). Internal branding: A university's most valuable intangible asset. Journal of Product and Brand Management, 18(5), 367-370. 
http://www.hurriyet.com.tr/teknoloji/bilisim-500-odulleri-sahiplerinibuldu-40888093, Erişim Tarihi: Aralık 2018.

http://www.hurriyet.com.tr/teknoloji/bilisim-500-odulleri-sahiplerinibuldu-40888093, Erişim Tarihi: Aralık 2018.

https://www.karel.com.tr/blog/2018-turkiye-bilisim-pazari, Erişim Tarihi: Ocak 2019.

https://www.karel.com.tr/blog/2018-turkiye-bilisim-pazari, Erişim Tarihi: Ocak 2019.

\section{Kaynakça Bilgisi / Citation Information}

Penpece-Demirer, D. ve Özer, E. (2019). Sosyal medyada markaların kullandığı içerik stratejisinin gönderi popülaritesindeki rolü: Türkiye'deki bilişim şirketleri üzerine bir uygulama. OPUSUluslararası Toplum Araştırmaları Dergisi, 10(17), 1344-1379. DOI: 10.26466/opus.523402 